\title{
Evaluation of Dam Decommissioning in an Ice-Affected River: Case Study
}

Carrie M. Vuyovich and Kathleen D. White

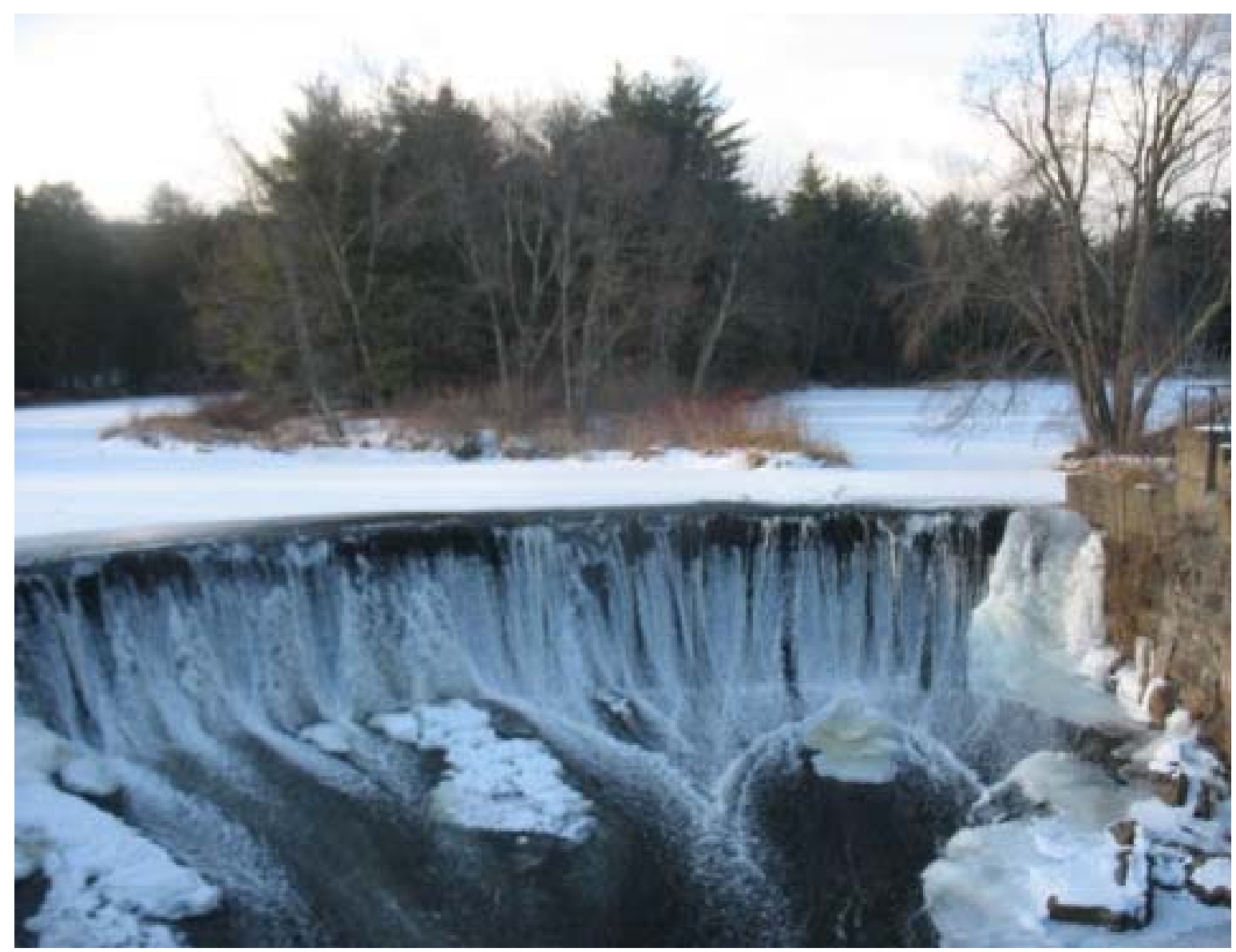


COVER: Merrimack Village Dam, looking upstream, taken from Chamberlain Bridge (Photo courtesy of Gomez \& Sullivan, Inc.) 


\section{Evaluation of Dam Decommissioning in an Ice-Affected River: Case Study}

Carrie M. Vuyovich and Kathleen D. White

Cold Regions Research and Engineering Laboratory

US Army Engineer Research and Development Center

72 Lyme Road

Hanover, New Hampshire 03755-1290

Final report

Approved for public release; distribution is unlimited.

Prepared for New England District, US Army Corps of Engineers

Concord, Massachusetts 01742-2751

Under Work Unit 989J28, “Ice-Affected Structures” 


\begin{abstract}
Many dams across the United States are being decommissioned as a result of structural deficiencies or a desire to restore fish passage and to restore the natural stream. On northern rivers, dam removal affects the river ice processes and can result in increased ice jams and ice jam-related flooding. An analysis of the river system prior to dam removal is often necessary to ensure that increased ice jams, flooding, and damages do not result. This case study presents the types of analyses needed to investigate the ice impacts of the potential removal of the Merrimack Village Dam on the Souhegan River in Merrimack, New Hampshire. Of particular interest were the potential impacts to the historic Chamberlain Bridge. A HECRAS hydraulic model was used to estimate the ice jam thickness and resulting water surface profiles with and without an ice jam in place for both the pre- and post-dam-removal conditions. The results of this analysis indicate that removing the Merrimack Village Dam will not pose significant risk to the Chamberlain Bridge or to the area downstream.
\end{abstract}

DISCLAIMER: The contents of this report are not to be used for advertising, publication, or promotional purposes. Citation of trade names does not constitute an official endorsement or approval of the use of such commercial products. All product names and trademarks cited are the property of their respective owners. The findings of this report are not to be construed as an official Department of the Army position unless so designated by other authorized documents. 


\section{Contents}

Figures and Tables................................................................................................................

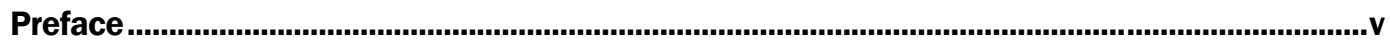

1 Introduction

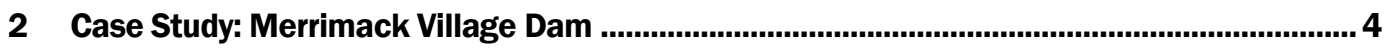

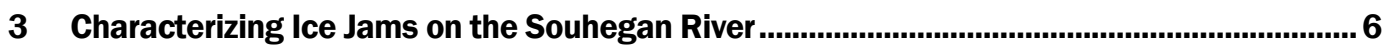

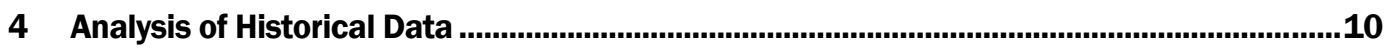

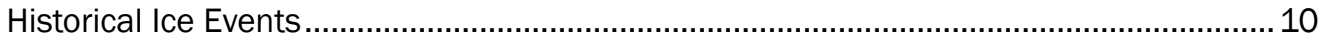

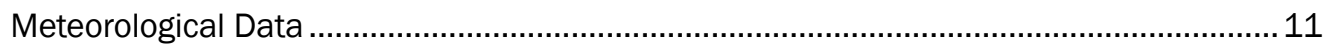

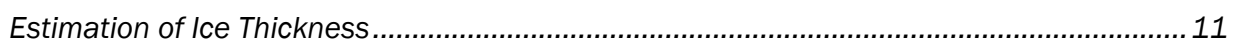

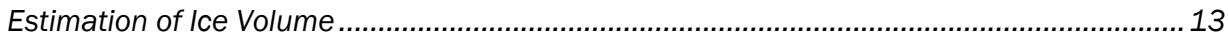

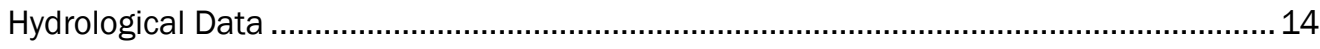

5 Ice Hydraulic Model ............................................................................................................16

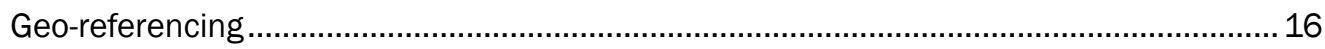

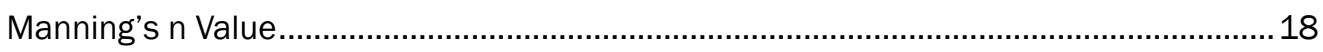

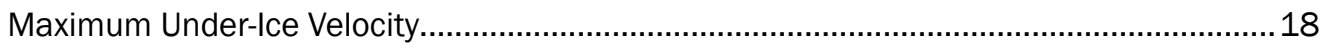

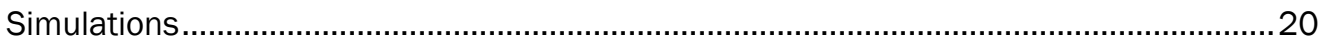

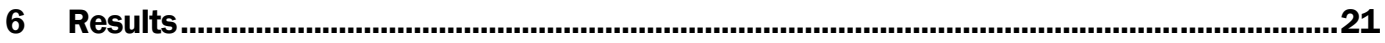

7 Ice Impacts Resulting from Merrimack Village Dam Removal .............................................30

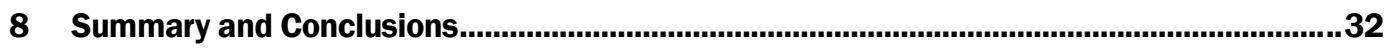

9 References

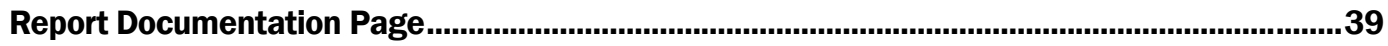




\section{Figures and Tables}

\section{Figures}

Figure 1. Souhegan River profile............................................................................................. 7

Figure 2. Lower Souhegan River and sediment deposits..................................................................... 8

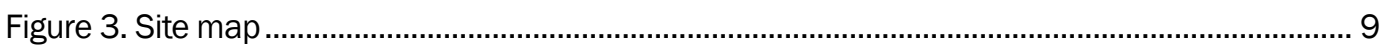

Figure 4. Estimated ice thickness for each year using Nashua, New Hampshire,

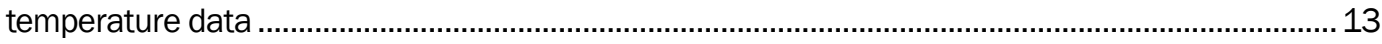

Figure 5. Example of ice-affected stage-discharge curve............................................................... 14

Figure 6. Geo-referenced HEC-RAS model of the lower Souhegan River ........................................ 17

Figure 7. Open-water profile for original and geo-referenced HEC-RAS models.................................18

Figure 8. HEC-RAS ice jam and open water profiles, with dam in place for the two-year

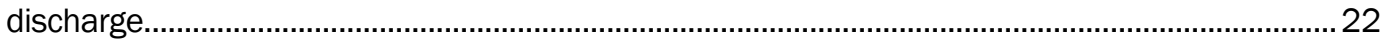

Figure 9. HEC-RAS ice jam and open water profiles, with dam in place for the ten-year

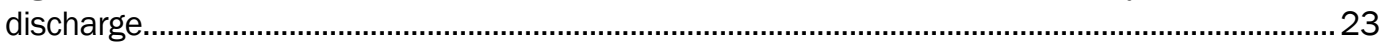

Figure 10. HEC-RAS ice jam and open water profiles, with dam removed for the two-year

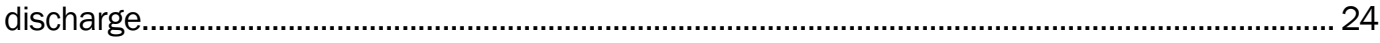

Figure 11. HEC-RAS ice jam and open water profiles, with dam removed for the ten-year

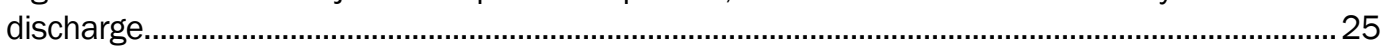

Figure 12. Estimate of ice jam locations and inundated areas with dam in place for the

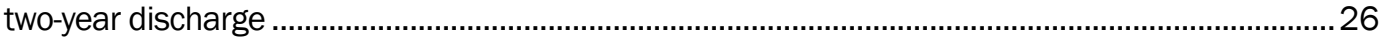

Figure 13. Estimate of ice jam locations and inundated areas with dam in place for the

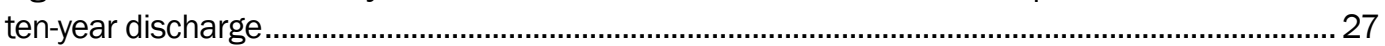

Figure 14. Estimate of ice jam locations and inundated areas with dam removed for the

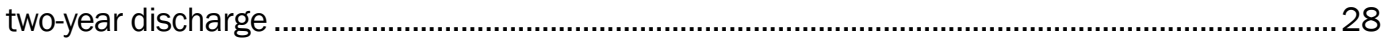

Figure 15. Estimate of ice jam locations and inundated areas with dam removed for the

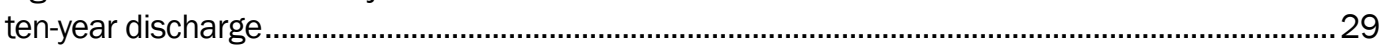

Figure 16. Chamberlain Bridge, looking downstream ................................................................... 30

\section{Tables}

Table 1. Summary of recorded Souhegan River ice jam events ..................................................... 11

Table 2. Summary of HEC-RAS ice properties used in model......................................................... 16

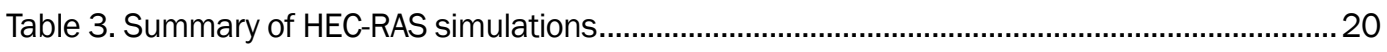




\section{Preface}

This report was prepared by Carrie M. Vuyovich, PE, Research Hydraulic Engineer, Remote Sensing/ Geographic Information Systems (RS/ GIS) and Water Resources Branch, and Dr. Kathleen D. White, PE, Research Engineer, Environmental Branch, US Army Engineer Research and Development Center (ERDC), Cold Regions Research and Engineering Laboratory (CRREL), Hanover, New Hampshire.

This work was prepared for the New England District, Army Corps of Engineers, and funded under the US Army Corps of Engineers Civil Wetlands Regulatory Assistance Program, managed by Robert L. Lazor, with additional support from the Flood and Coastal Storm Damage Reduction Research Program Work Unit 989J 28, Ice-Affected Structures. Technical reviews were provided by Dr. Steven F. Daly, PE, Research Hydraulic Engineer, and by Andrew M. Tuthill, PE, Research Hydraulic Engineer, both of whom are in the RS/ GIS and Water Resources Branch, CRREL.

This report was prepared under the general supervision of Timothy Pangburn, PE, Chief, RS/ GIS and Water Resources Branch; Dr. J ustin B. Berman, Chief, Research and Engineering Division, CRREL; and Dr. Robert E. Davis, Director, CRREL.

At the time this work was performed, Colonel Richard B. J enkins was Commander and Executive Director of ERDC. Dr. J ames R. Houston was Director. 


\section{Introduction}

More than 2.5 million dams were built in the United States over the past several hundred years to meet the power, water supply, flood control, and recreational needs of a variety of users (National Research Council 1992). These dams range in size from small farm pond dams less than six ft in height to the 770-ft-tall Oroville Dam completed in 1968.

Despite the large number of recently built dams, Doyle et al. (2003) noted that the period 1950- 1970 could be termed the "golden age of dam building," with tens of thousands of dams built each decade. The Federal Emergency Management Agency (FEMA) (2001) estimated that by 2020, 85\% of large dams would be at or nearing their design lifespans. The American Society of Civil Engineers (ASCE) report card gave dams a grade of D in 2005, primarily due to increasing numbers of unsafe dams (ASCE 2005). The grade is based on the following observations:

- Between 1998 and 2005, the number of unsafe dams rose by 33\%.

- Because of constrained budgets, the number of unsafe dams is increasing faster than those being repaired.

- The combination of rapid downstream development and inadequate past design practices, coupled with a predicted increase in extreme events, increases life safety risks.

ASCE (2005) notes that "On the federal side, federally owned and federally regulated hydropower dams are in good condition; however, continuing budget restrictions and increased attention to security are placing pressure on and limiting many agency dam safety programs." The US Army Corps of Engineers (USACE) owns and operates 608 dams (USACE 2005a), of which 113 are concrete dams and the remaining are earthen embankments, rockfill, or timber crib dams. More than a quarter of these dams are more than 50 years old (Bowles et al. 1999). According to McGrath (2000), the Corps has 356 high-hazard, 36 significant-hazard, and 15 low-hazard embankment dams. Between 1990 and 2005, the National Performance of Dams Program (NPDP 2005) reported 15 Dam Incident Notifications for Corps dams, but no failures. The statistics are worse for the 
thousands of non-Federal dams: during the two year period 2003-2005, the NPDP reported more than 67 incidents including 29 failures (ASCE 2005).

Increased awareness of the ecological, recreational, and economic issues, in addition to safety issues associated with dams, has led to reevaluation of their continuing usefulness (American Rivers et al. 1999, American Institute of Biological Sciences 2002, Heinz Center 2002). Interest in dam decommissioning, including dam removal, has grown substantially over the past 20 years. Decommissioning alternatives include dam removal, which is often assumed to be synonymous with decommissioning; the use of nature-like fishways to bypass a dam (e.g., the USACE's New Savannah Bluff Lock and Dam By-Pass); the use of rock arch ramps or boulder vanes (e.g., USACE projects on the Red River of the North at Fargo and Grand Forks); partial breaching (e.g., USACE projects on the Chattahoochee River); and dam reoperations, which the USACE is pursuing at several locations with The Nature Conservancy.

Most experts recommend a careful examination of potential impacts of dam removal (ASCE 1997, Heinz Center 2002, Conyngham et al. 2006), but the temptation exists to oversimplify the situation. For example, American Rivers (2002), summarizing work by Bednarek (2001), states "Though there are some negative ecological impacts associated with dam removal, Bednarek observes that most of these impacts have short-term effects on a river system." This attitude, combined with restoration costs ranging to more than three times the cost of removal (Born et al. 1998), can result in less-than-thorough alternatives analyses.

Dam decommissioning is a non-trivial issue that requires scientific, sociological, and economic analyses. The cumulative impacts of dam construction, human activities such as urbanization and deforestation, and natural events, can significantly disrupt the dynamic equilibrium of a river. Yet, watersheds do reach some new equilibrium state, which is then subject to further disturbance by dam decommissioning alternatives. The system changes resulting from decommissioning must be carefully studied to avoid unintended consequences, especially in the case of older dams.

Decision-making for dam decommissioning should address the degree of potential impact and recovery potential of the alternatives. Physical and economic constraints and public perceptions should be considered. Deci- 
sion-makers should rely on appropriate quality and quantity data and analyses resulting in acceptable levels of risk and uncertainty. Nontraditional methods of cost allocation such as game theory have been used in evaluating decommissioning alternatives (Tanimoto 2003). The use of contingent valuation and multi-objective decision models should also be considered (see, e.g., Abdul-Mohsen 2005 and Kuby et al. 2005).

Conyngham et al. (2006) provide an overview of the ecological and engineering aspects of dam decommissioning, with an emphasis on dam removal. Of particular interest to the USACE as a major water resource manager is the potential for significant affects on the timing and peak values of flood hydrographs due to dam removal (ASCE 1997). Typical dam removal studies address open-water impacts of dam removal. However, as White and Moore (2002) point out, dam removals on northern rivers can also significantly affect the ice formation, growth, and breakup processes.

There are several examples of dam removals resulting in changed ice conditions that increased the frequency and severity of damaging floods (Tuthill and White 1997, White and Moore 2002, Vuyovich and White 2006, Tuthill et al. 2007). One important way dam removal can modify the river ice conditions is by allowing ice at breakup to travel farther downstream. Ice that was held upstream of the dam can reach locations downstream where ice jams have not occurred since the dam was built. As a result, development and infrastructure, such as bridges, downstream of the dam may be susceptible to ice damage. White (2001) suggested steps that can be taken to evaluate ice impacts over and above those suggested by ASCE (1997). This method was developed further by Vuyovich and White (2006) in an analysis of the effectiveness of an ice control structure. The current technical report presents a case study illustrating the analyses required to perform an evaluation of the impacts of dam decommissioning in an ice-affected river. 


\section{Case Study: Merrimack Village Dam}

The Merrimack Village Dam is located at Merrimack, New Hampshire, on the Souhegan River approximately 2,000 feet upstream of the confluence with the Merrimack River. The present structure, an arched ogee spillway, has been in place since 1934. A dam has existed at the site since the early 1900s. The dam currently is not used for its intended purposes of hydropower or water storage, and recent inspections have uncovered deficiencies that need to be addressed. Removal of the Merrimack Village Dam would address the deficiencies and would provide the additional benefit of stream restoration (Gomez and Sullivan 2004).

Ice forms on the Souhegan River nearly every winter and is an important consideration in determining the impact of the removal of the Merrimack Village Dam on the Souhegan River ice conditions. Thus, the project makes an ideal case study, in which the objective is to investigate the impacts of the Merrimack Village Dam removal on the formation of potentially damaging ice jams downstream.

The case study follows the method presented by White (2001) and expanded upon by Vuyovich and White (2006). First, the historical ice jam reports and river geomorphology were analyzed to determine the most likely location for ice jams to occur once the dam is removed. In this case, it was assumed that ice will be able to pass farther downstream without the dam in place, though the bedrock formation beneath the dam is unknown. Based on that assumption, the most likely location for an ice jam to occur without the dam in place is at the upstream extent of the Merrimack River backwater, which extends approximately 1,000 feet upstream from the mouth of the Souhegan River. Of specific concern were ice impacts on the historic Chamberlain Bridge, located approximately 130 feet downstream of the Merrimack Village dam.

The ice conditions likely to be in place in the Souhegan River at the time of jam formation were then determined by reviewing historical meteorologi$\mathrm{cal}$ and hydrological data to estimate ice thickness, ice jam volume, and a range of likely discharges during an ice jam event. Next, a HEC-RAS hydraulic model (USACE 2006) of the Souhegan River was used to estimate the ice jam thickness and resulting water surface profiles throughout the 
Souhegan River. The HEC-RAS model was used to determine water surface profiles both with and without an ice jam in place to simulate pre- and post-dam-removal conditions. The HEC-RAS model was geo-referenced using GIS and GeoRAS (USACE 2005b) software to produce flood inundation maps of the pre-and post-dam removal ice jam scenarios in GIS. Finally, the ice jam results through the Chamberlain Bridge are reviewed in detail. Each of these steps is described in detail in the following sections. 


\section{Characterizing Ice Jams on the Souhegan River}

The formation of breakup ice jams is strongly influenced by the winter weather conditions, the river discharge, and the river's geomorphology. The influence of the winter weather can be understood by examining the winter air temperatures. A strong relationship exists between the thickness of thermally grown ice and the number of accumulated freezing degree days that occur during the winter. Mechanical breakup occurs when there is sufficient flow to break up the solid ice cover and transport it downstream. Breakup jams often occur during warming periods that cause the ice cover to deteriorate to some degree, but warm temperatures without an increase in discharge generally lead to a thermal melt-out of the ice (USACE 2002). Ice jams occur at locations with limited ice conveyance, such as at sharp bends or channel constrictions, at bridges and other structures obstructing flow, or where the river slope decreases. All of these factors combined make predicting jams difficult without prior observations.

The Souhegan River is approximately 34 miles long with a drainage area of roughly $220 \mathrm{mi}^{2}$. The upstream portion of the river is relatively steep, and numerous dams have been built in this reach for hydropower and flood control (Gomez and Sullivan 2004). It is likely that the dams upstream reduce the amount of ice that travels to lower portions of the river. The McClane Dam, in Milford, New Hampshire, lies approximately at the midpoint of the river, below the Souhegan's steep upper half. Ice jams have been reported at the McClane Dam (IJ DB 2007). Figure 1 shows the Souhegan River profile extending 30 miles upstream from the mouth.

Below the McClane Dam, at Milford, the Souhegan River flattens out significantly for 12 miles before reaching a series of rapids called Wildcat Falls in Merrimack, New Hampshire. Approximately one mile upstream of the rapids, the river forms a sharp oxbow, which is the location of several reported ice jams. A report (USACE 1980) on historical ice jams in Maine, New Hampshire, and Vermont conducted by the New England Division (now New England District) Corps of Engineers states that in nine of the 11 years between 1969 and 1980, a jam formed at this oxbow, sometimes causing minor flooding. According to the report, "The jam remains in 
place until it melts, or until pressure from water and upstream ice force the jam to break up. Downstream of the ice jam, the Souhegan flows freely and once the jam breaks up, it moves downstream without further jamming." Without additional analysis it would be difficult to determine the release discharge from the oxbow. It is likely that a solid ice cover at the impoundment stops ice released from the oxbow without causing any damage, until the discharge is sufficient to carry the ice over the dam or the ice accumulation melts in place.

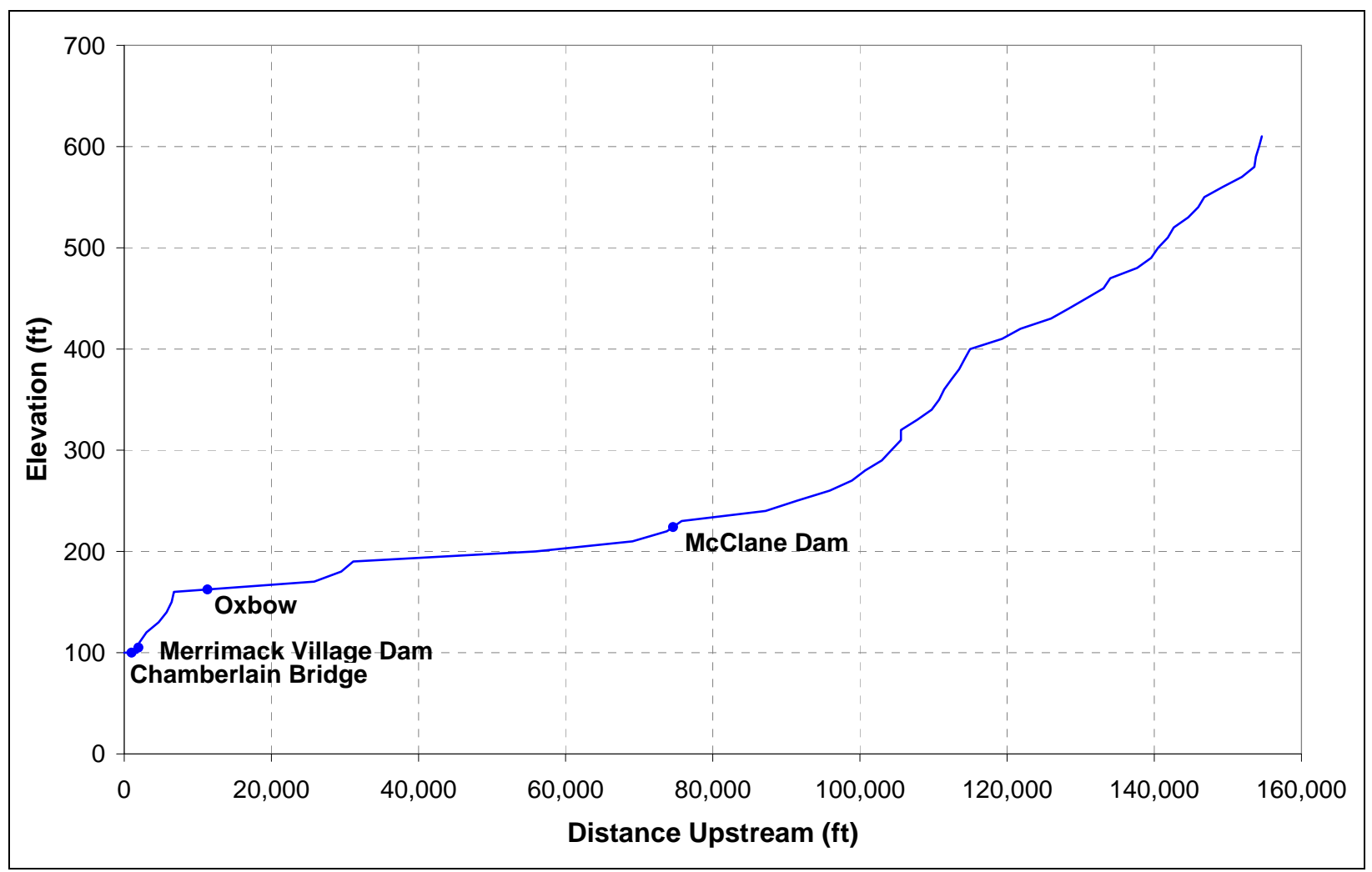

Figure 1. Souhegan River profile.

Frazil ice is produced in open water reaches with a steep gradient during periods of sub-freezing temperatures. Once frazil ice encounters a slowmoving reach of the river, it tends to accumulate against and beneath thermally grown ice, thickening and strengthening the ice cover. It is likely that significant amounts of frazil ice are produced in the section of rapids between the oxbow and the impoundment. Frazil ice that currently deposits beneath the ice cover at the impoundment is likely to travel farther downstream once the dam is removed.

A sediment island in the Souhegan River marks the upstream extent of the Merrimack River backwater (Fig. 2). This island is located approximately 
1,000 feet upstream of the confluence with the Merrimack River and 800 feet downstream from the dam. Typically, sediment settles out when fastmoving river reaches a slow-moving section, such as the backwater of a larger river at a confluence. Frazil ice settles out under similar conditions, accumulating on the underside of an ice cover rather than in the channel bed. Once the dam is removed, frazil ice generated in the Wildcat Falls reach likely will pass through the Chamberlain Bridge and deposit near the sediment island, creating a solid, strong ice cover. This island represents the most likely locations for ice jams to occur once the dam is removed. A site map is shown in Figure 3.

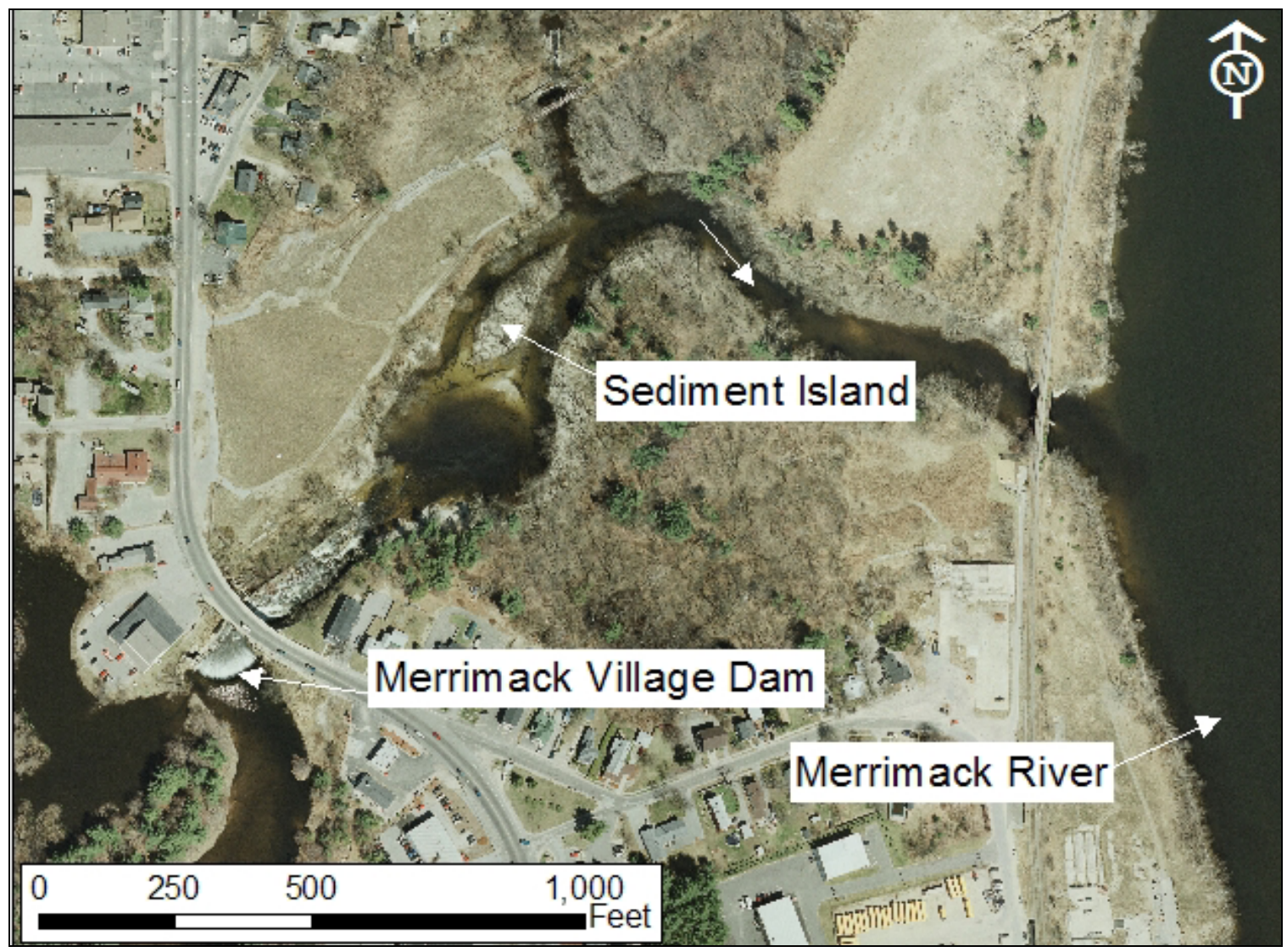

Figure 2. Lower Souhegan River and sediment deposits. (Photo courtesy of Gomez and Sullivan.) 


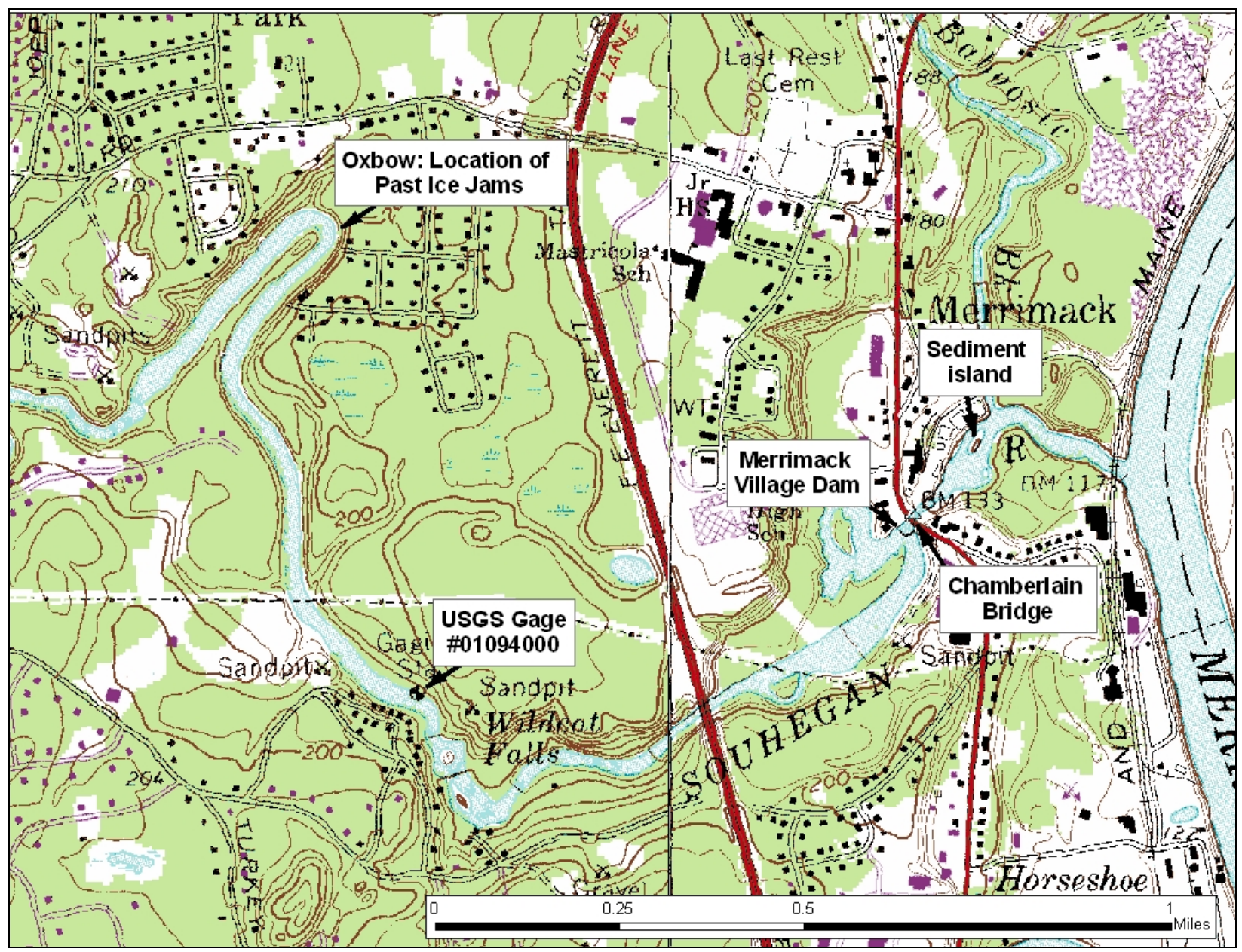

Figure 3. Site map. (Source: USGS topographical map, Nashua North, New Hampshire.) 


\section{Analysis of Historical Data}

Standard investigations of river ice jam occurrence (Tuthill et al. 2003, Vuyovich et al. 2005) include an extensive review of recorded ice events and analysis of meteorological and hydrological data at relevant stations. Historic ice jam events were reviewed for information on where jams occur, resulting stage increases, damages, and relevant conditions at the time of the event. Meteorological data were used to estimate ice thickness and ice volume contributing to the ice jam. Hydrological data were used to determine the range of discharges at which an ice jam could exist. This information is used to develop the input parameters for the HEC-RAS model.

\section{Historical Ice Events}

This study included a limited review of historical ice events using the CRREL Ice J am Database and the New England District of the Army Corps of Engineers' online library of documents. A more comprehensive search of newspaper and town archives possibly could have uncovered additional events or details, but was beyond the scope of the current effort. This review revealed an active ice regime on the Souhegan River.

There are three recorded ice jams on the Souhegan River in Merrimack in the Ice J am Database (IJ DB 2007). The 1977 event came from a report by the New England Division (now New England District), US Army Corps of Engineers (USACE 1980). According to the report, nine ice jams occurred between 1970 and 1980, with the jam of March 1977 being the worst. According to an interview with local officials, "The jam [occurred] at one of the oxbows in the Souhegan River, approximately 8,000 feet upstream of the F.E. Everett Turnpike Bridge." The two other jams (1964 and 1968) were reported at the USGS Souhegan River gage at Merrimack. These reports typically do not give specific details regarding location or damages. It is likely that these jams also occurred at the oxbow, which is located approximately 4,000 feet upstream of the gage.

Based on the frequency of jams reported in the USACE report, it is reasonable to assume that additional ice jams have occurred that did not cause serious damages and therefore were not reported. Often historical ice event data are not readily available or reported. One reason for the under- 
reporting of ice events involves perception stage (Gerard and Karpuk 1979), which is defined as the minimum stage at which a source will perceive an event. If an ice jam occurs, but does not exceed the perception stage, most observers do not report the event. Table 1 summarizes the historical record of ice jams, along with temperature and discharge data associated with the events.

Table 1. Summary of recorded Souhegan River ice jam events.

\begin{tabular}{|c|c|c|c|c|c|}
\hline Date & Description/location & $\begin{array}{c}\text { Time to } \\
\text { peak } \\
\text { (days) }\end{array}$ & $\begin{array}{c}\text { Average daily } \\
\text { discharge } \\
\text { (cfs) }\end{array}$ & $\begin{array}{c}\text { AFDD } \\
\text { ('F-days) }\end{array}$ & $\begin{array}{c}\text { Estimated ice } \\
\text { thickness } \\
\text { (in.) }\end{array}$ \\
\hline 10 March 1964 & Ice jam reported at gage & 3 & 1,100 & 834 & 14.4 \\
\hline 19 March 1968 & Ice jam reported at gage & 3 & 3,800 & 994.5 & 15.8 \\
\hline \multicolumn{7}{|c|}{$\begin{array}{c}\text { oxbow 8000' u/s of } \\
\text { Everett Turnpike Bridge }\end{array}$} & $\begin{array}{c}\text { No data } \\
\text { available }\end{array}$ & $\begin{array}{c}\text { No data } \\
\text { available }\end{array}$ & 985 & 15.7 \\
\hline $\begin{array}{l}9 \text { jams between } \\
1969 \text { and 1980 }\end{array}$ & $\begin{array}{c}\text { oxbow 8000' u/s of } \\
\text { Everett Turnpike Bridge }\end{array}$ & & $1,800-3,200 *$ & $805.9 \dagger$ & $14.2 * *$ \\
\hline $\begin{array}{l}* \\
+\quad \text { Based on maximum winter discharge for years of available data (1969-1976) } \\
* * \text { Ice thickness based on average AFDD }\end{array}$ \\
\hline
\end{tabular}

\section{Meteorological Data}

Air temperature data are used to estimate ice thickness as well as to analyze historical ice events. Ice thickness is a necessary input parameter to HEC-RAS for modeling an ice cover or ice jam event. Ice thickness was also used to estimate the ice volume contributing to an ice jam.

Daily maximum and minimum air temperature data were retrieved from National Weather Surface (NWS) meteorological stations. The NWS station \#275712 in Nashua, New Hampshire, with a period of record from 1885 through the present, was the primary source of temperature data.

\section{Estimation of Ice Thickness}

Ice growth on a water surface is a function of heat transfer at the ice/ water interface. Temperature data were used to estimate ice thickness on the Souhegan River based on accumulated freezing degree days (AFDD) (White 2004). In this method, thermally induced (but not frazil) ice thickness can be estimated on a given date during the winter using temperature 
data in the previous months. Freezing degree-days (FDD) represent the difference between the average daily air temperature $\left(\mathrm{T}_{\mathrm{a}}\right)$ and $0^{\circ} \mathrm{F}$, where a difference in temperature below freezing is positive and above freezing is negative. Accumulation of FDD begins in the fall when temperatures drop below freezing and continues throughout the winter. The peak annual net AFDD is a good indicator of winter severity. AFDD can provide an estimate of ice thickness ( $t_{\text {ice }}$ ) in inches on a particular day using the modified Stefan equation presented in USACE (2002):

$$
t_{\text {ice }}=C \sqrt{A F D D}
$$

where $C$ is a coefficient, usually ranging between 0.3 and 0.6, and AFDD is in ${ }^{\circ} \mathrm{F}$-days. A coefficient of 0.5 was used to calculate ice thickness in Merrimack based on suggested values for the river type (USACE 2002). In general, the ice thickness used in the HEC-RAS ice routine does not greatly affect the results as long as the value used is within a reasonable range.

Although this method provides a reasonable estimate of ice growth caused by thermal processes, it is important to note that the ice thickness may be underestimated because of other factors, such as water velocity and the presence of a snow cover on top of the ice. Also, frazil ice deposition can contribute to ice thickness. Figure 4 shows the estimated maximum ice thickness caused by thermal growth for each year of record. Based on the AFDD analysis, the average maximum annual ice thickness on the Souhegan River is 13.4 inches (1.12 ft). 


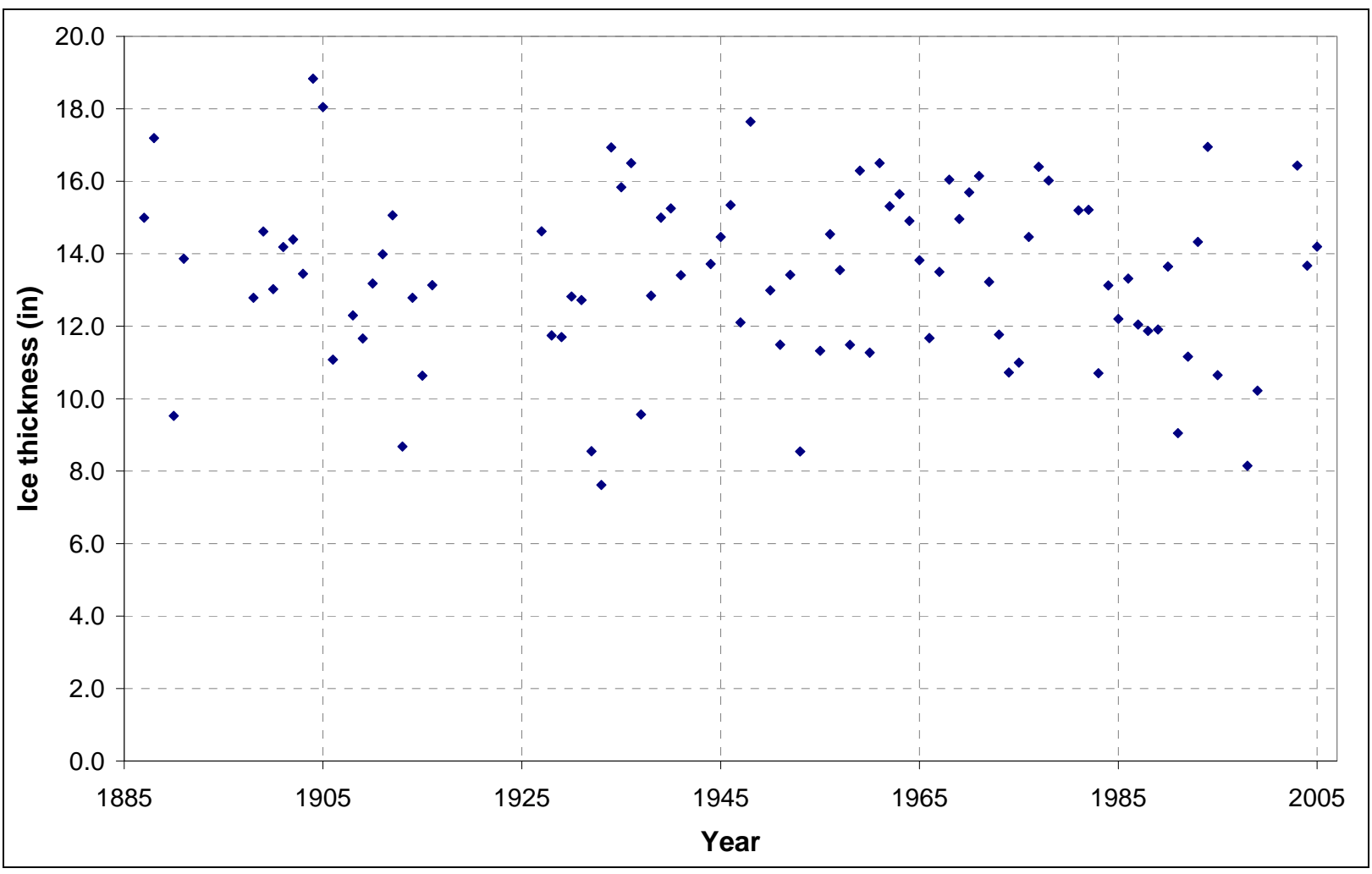

Figure 4. Estimated ice thickness for each year using Nashua, New Hampshire, temperature data.

\section{Estimation of Ice Volume}

The volume of ice that contributes to an ice jam determines the thickness and length of the jam. Calculating ice volume involves the following steps: 1) estimate surface area of ice and multiply by average ice thickness to get total volume; 2) determine ice transport losses based on channel morphology and historical records, if any; 3) decrease total ice volume by transport losses to determine ice volume available to jam.

In this case study, the contributing reach extends 14 miles upstream to the McClane Dam in Milford, New Hampshire. Surface area was estimated using a USGS topographic map of the area. Ice thickness was calculated using the AFDD method described above. The ice volume is reduced during transport, either stranded in the overbanks or eroded as a result of friction. The percentage of the ice volume lost depends largely on the characteristics of the specific reach. Earlier estimates ranged from $20 \%$ to $80 \%$ (Lever et al. 2000). Losses of 50\% were used for this relatively small reach because the discharge is largely contained within the channel at breakup flows. Some ice is expected to be lost during a jam at the oxbow, and in fast-moving sections or rapids it is unlikely that a solid ice cover ever 
forms. The total volume of ice estimated to contribute to a jam in the lower Souhegan River is 3,500,000 $\mathrm{ft}^{3}$. A sensitivity analysis showed that, within a reasonable range, using a lower or higher volume of ice in the model will impact only the upstream extent and thickness of the ice jam. The ice jam formation through the Chamberlain Bridge and up to the current location of the Merrimack Village Dam will not be impacted.

\section{Hydrological Data}

Discharge data are used to analyze historical ice events and develop a range of discharges at which an ice event is likely to occur. The discharge range at which an ice jam can form and release depends on the ice thickness and ice strength. Sufficient flow is required to break up a solid ice cover and transport it downstream. A gradual rise in flow over many days or weeks often will weaken and melt the ice cover in place, thereby avoiding a dynamic breakup. Significant events generally result from a rapid rise in discharge that breaks up a strong ice cover and transports the ice downstream to a point where the downstream forces are not enough to convey the ice through and it jams. At some greater discharge the ice jam may release when it can no longer withstand the downstream forces. Figure 5 illustrates the process from competent ice cover to breakup to jamming, followed by jam failure.

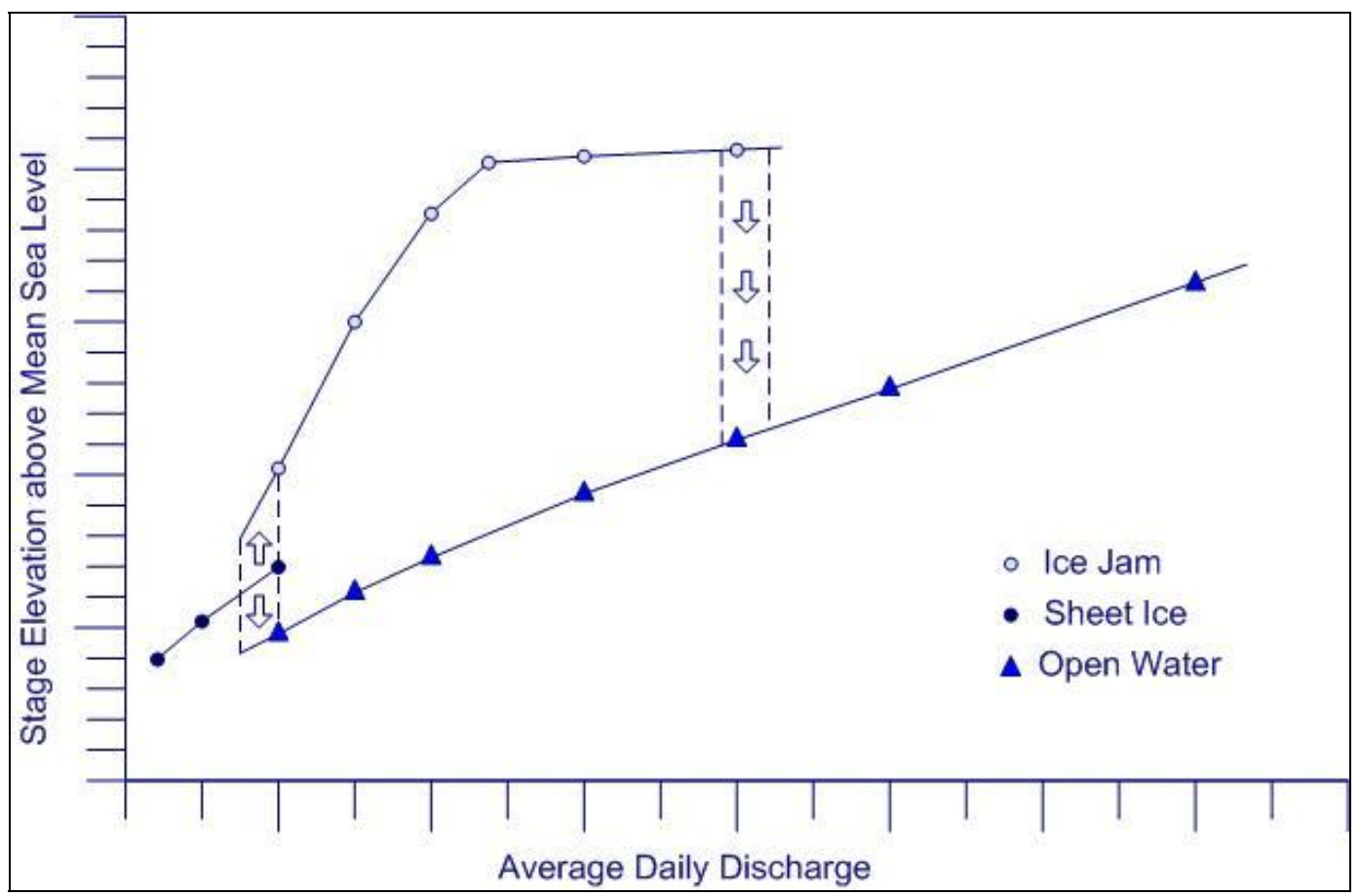

Figure 5. Example of ice-affected stage-discharge curve. (After Tuthill et al. 1996.) 
Average daily river discharge data were obtained from USGS Gage \#01094000 (USGS 2007a), which is located on the Souhegan River at Merrimack, New Hampshire, approximately one mile upstream from the dam, and has a drainage area of 171 square miles. This gage has a period of record dating from 1907 through the present, though a gap in the data exists between 1976 and 2001. The Merrimack River gage at Goffs Falls (USGS gage \#01092000; USGS 2007b) was used to observe the pattern of increasing and decreasing discharge when Souhegan River data were unavailable.

The maximum discharge an ice jam can withstand before failure typically results in the highest stages and represents the worst-case scenario. The maximum discharge reached during a recorded ice event was 3,800 cfs in 1968. Between 1969 and 1976, nine ice jams were reported, but exact dates are not known. The maximum discharge during those winters, when Souhegan River discharge data are available, ranged between 1,800 and 3,200 cfs. The maximum ice jam discharge on the Souhegan River may be greater than the discharge available for known jams, but it is unlikely that a significantly larger event occurred that was not recorded. 


\section{Ice Hydraulic Model}

The USACE Hydrologic Engineering Center's River Analysis System (HEC-RAS) is used to perform one-dimensional analysis of a river system (USACE 2006). The additional capability to model wide-river ice jams (Daly et al. 1998, Tuthill et al. 1998) makes it a useful tool for evaluating the impacts of a channel modification project on rivers with an active ice regime. A calibrated open-water HEC-RAS model developed for this reach of the Souhegan River by Gomez and Sullivan (2004) was geo-referenced and modified to simulate ice conditions. The reach was modeled with and without the dam in place in both open-water and ice-affected conditions.

A number of material properties of ice need to be input to HEC-RAS to model an ice jam (e.g., White 1999). Table 2 lists the property values used in this study. Default values supplied in HEC-RAS for the specific gravity of ice, the angle of internal friction, the porosity of the ice accumulation, and the ratio of lateral to longitudinal ice stresses were considered reasonable for this application. Estimates for other parameters that required additional analysis are described below.

Table 2. Summary of HEC-RAS ice properties used in model.

\begin{tabular}{|c|c|}
\hline HEC-RAS ice properties & Value used in model \\
\hline Specific Gravity of Ice & 0.916 \\
\hline Angle of Internal Friction & $45^{\circ}$ \\
\hline Porosity of Ice Accumulation & 0.4 \\
\hline Ratio of Lateral to Longitudinal Ice Stresses & 0.33 \\
\hline Manning's $n$ value & $0.7 *$ \\
\hline Maximum Under-Ice Velocity & $15 \mathrm{fps}^{+}$ \\
\hline \multicolumn{2}{|c|}{$\begin{array}{l}\text { 1*Allowed to change based on ice thickness within ice jam extent. } \\
+ \text { Within ice jam extent. Default value ( } 5 \mathrm{fps} \text { ) used in all other areas. }\end{array}$} \\
\hline
\end{tabular}

\section{Geo-referencing}

This model was geo-referenced to provide an effective way of displaying the results of the ice-affected runs (Fig. 6). The geo-referenced cross sections were merged with the existing cross sections so that the original geometry remained the same. The open water models of both pre- and 
post-dam removal conditions were simulated and compared to the original results. The geo-referenced water surface profiles matched the original profiles to within $0.01 \mathrm{ft}$ at every cross section. Figure 7 shows the georeferenced profile results for the open water pre-dam removal test compared to the original results.

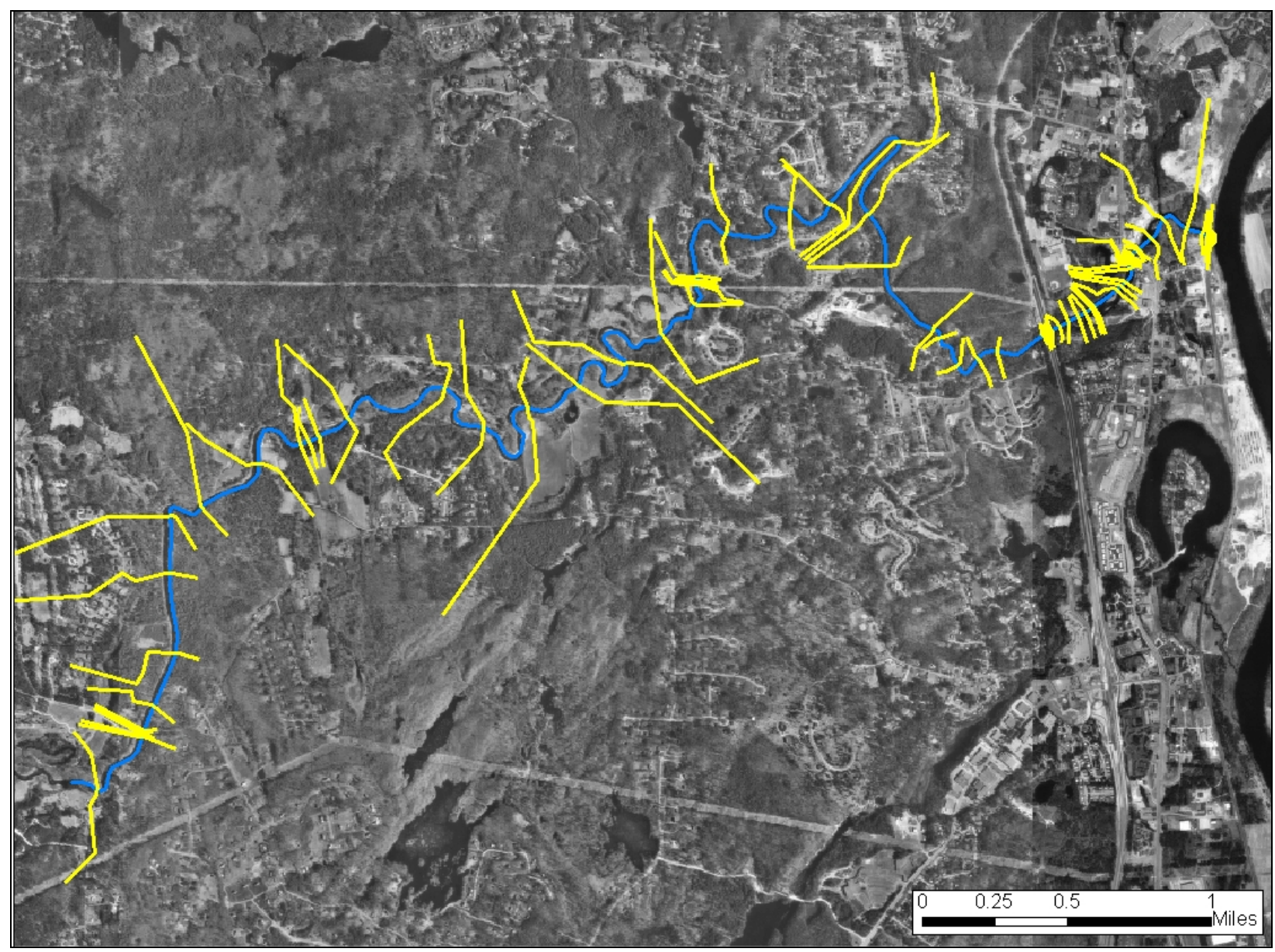

Figure 6. Geo-referenced HEC-RAS model of the lower Souhegan River. 


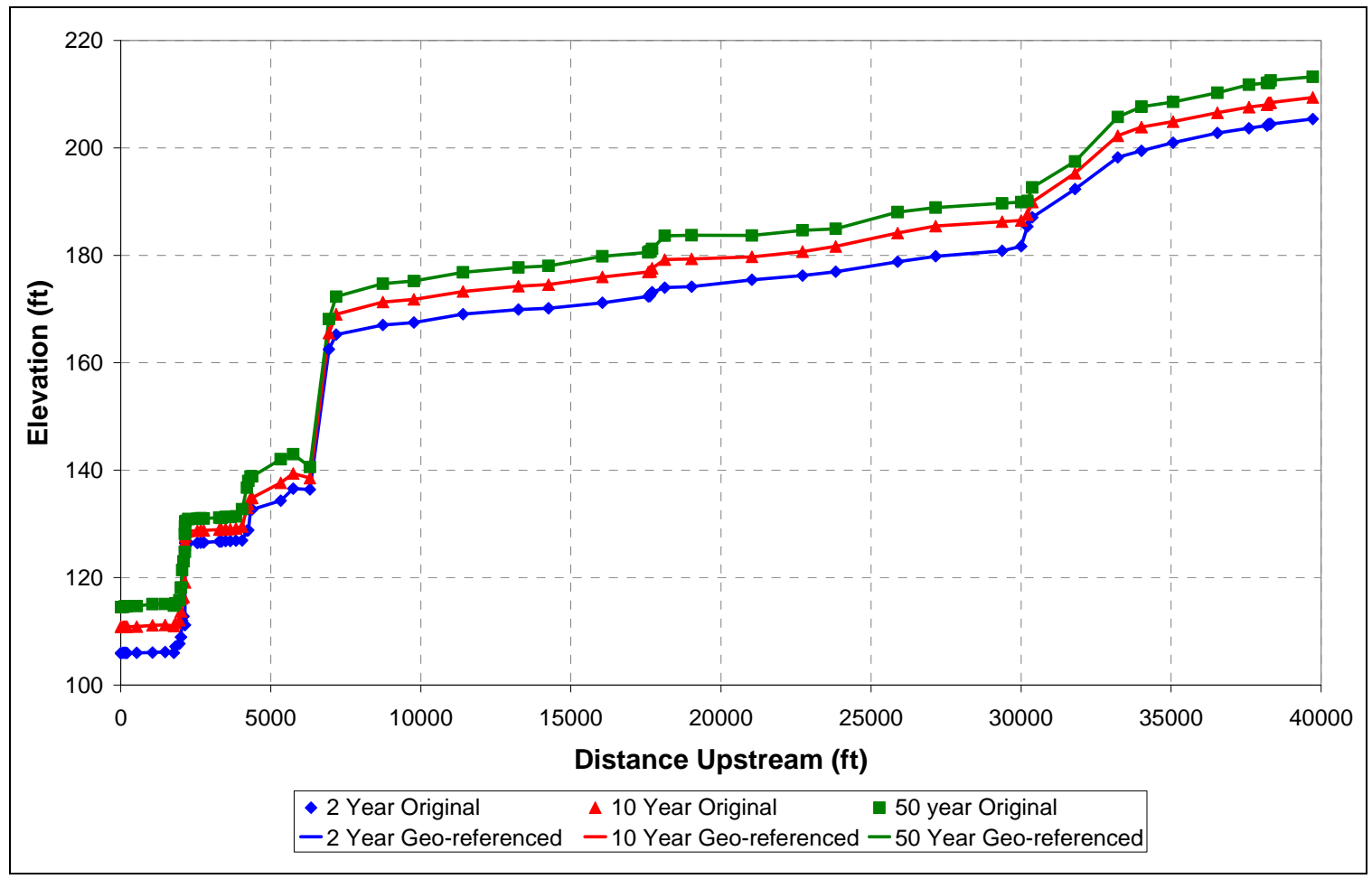

Figure 7. Open-water profile for original and geo-referenced HEC-RAS models.

\section{Manning's n Value}

The initial Manning's $n$ value used for the roughness of the ice cover was 0.07, which was the recommended default value in HEC-RAS and a reasonable value for this application (White and Daly 1997). Within the ice jam reach, the option to vary the Manning's $n$ value based on the thickness of the jam was selected in HEC-RAS.

\section{Maximum Under-Ice Velocity}

The maximum under-ice velocity parameter used in HEC-RAS is a useful modeling tool that prevents the ice jam from thickening to the bed and blocking the entire channel with ice (USACE 2006). HEC-RAS estimates the thickness of a floating wide river jam by solving the ice jam force balance equation. If the calculated flow velocity under the jam reaches the value of the maximum under-ice velocity set by the user, the ice jam thickness is not allowed to increase further during the solution procedure. In this case, the ice jam force balance equation cannot be solved and the estimated jam thickness may be suspect. If the maximum under-ice velocity is reached along significant lengths of the ice jam, the value of the maximum under-ice velocity parameter may be increased, but there should be some physical justification for doing this. 
The concept of a maximum under-ice velocity has been used in a number of numerical and physical model studies of ice jams (Tuthill et al. 1998, Healy et al. 1997, Flato and Gerard 1986). There is a physical basis for a maximum under-ice velocity based on erosion of ice pieces from the underside of a floating jam with full-width water flow beneath. For this type of classic wide river jam, scaled erosion velocities ranging from 3.3 to 6.6 $\mathrm{ft} / \mathrm{s}(1.0$ to $2.0 \mathrm{~m} / \mathrm{s}$ ) have been measured in physical models (Tuthill and Gooch 1998) and in the field by Beltaos and Moody (1986). The concept of an under-ice erosion velocity assumes a floating ice jam with a relatively uniform under-ice flow depth and uniform water velocity across the channel.

If an ice jam is partially grounded, or the ice accumulation is mechanically locked in place by channel obstructions, under-ice erosion velocities higher than cited in the literature may be possible. For example, an ice jam may form in a steep reach upstream of the intact sheet ice on a dam impoundment. As the discharge continues to rise, water velocities in portions of the channel may exceed the commonly accepted non-eroding maximum of about $6 \mathrm{ft} / \mathrm{s}$. In these higher flow areas, ice pieces may erode away, developing preferential high velocity flow paths beneath the jam, while the bulk of the ice accumulation remains stable and mechanically locked in place. Tuthill (in prep) observed this process in a physical model study of a pier-type ice control structure, and measured flow velocities that were much higher than the commonly accepted 4- to 6-ft/s upper threshold for non-erosion of ice pieces. Another example is an ice jam that commonly forms on a steep section of the Mad River above a small reservoir near Moretown, Vermont. In this rapids section, high velocity flow erodes a channel beneath and through the jam, but because the ice accumulation has nowhere to go, the jam remains in place throughout the bulk of the breakup period.

On the Souhegan River, an ice jam located in the Merrimack River backwater would be restricted by the downstream ice cover, the channel banks, and the Chamberlain Bridge abutments as it extends upstream. Velocities immediately upstream of the bridge can range from 10 to $15 \mathrm{ft} / \mathrm{s}$ during open water flow. If the maximum under-ice velocity parameter is set too low within this reach, the thickness of the jam will be artificially reduced. For this study, the maximum under-ice velocity was set to $15 \mathrm{ft} / \mathrm{s}$ within the ice jam extent to allow the ice jam to progress up the steep section from the Merrimack backwater past the Chamberlain Bridge. 


\section{Simulations}

For this analysis, the two-year and the ten-year open water flood flows, based on the Federal Emergency Management Agency's Flood Insurance Study for the Town of Merrimack, were used to model the range of maximum ice jam discharges (FEMA 1979). At the location of the ice jam, the two-year discharge is 3,200 cfs and the ten-year discharge is 8,370 cfs. Based on the review of hydrologic data and historical ice events, the actual maximum discharge an ice jam could withstand on the Souhegan River is estimated to be between these two discharges.

To model the existing conditions, the toe of the jam was located at the upstream end of the impoundment behind the dam where the ice is likely to encounter a solid ice cover. To model the conditions once the dam is removed, the toe of the jam was located at the downstream end of the sediment island where the ice is likely to encounter a solid ice cover in the backwater of the Merrimack River. Table 3 gives a summary of each model run.

Table 3. Summary of HEC-RAS simulations.

\begin{tabular}{|c|c|c|c|c|}
\hline Run & Location of jam toe & $\begin{array}{c}\text { Discharge } \\
(\mathrm{cfs})\end{array}$ & $\begin{array}{c}\text { Ice jam extent } \\
\text { upstream } \\
(\mathrm{ft})\end{array}$ & $\begin{array}{c}\text { Total volume } \\
\left(\mathrm{ft}^{3} \text { ) }\right.\end{array}$ \\
\hline Existing conditions & Upstream end of impoundment & 3,140 & 3,487 & $3,528,095$ \\
\hline Existing conditions & Upstream end of impoundment & 8,370 & 1,483 & $3,650,594$ \\
\hline Dam removed & $\begin{array}{c}\text { Sediment island, 1000 ft } \\
\text { u/s of Merrimack River }\end{array}$ & 3,140 & 3,144 & $3,657,230$ \\
\hline Dam removed & $\begin{array}{c}\text { Sediment island, 1000 } \mathrm{ft} \\
\text { u/s of Merrimack River }\end{array}$ & 8,370 & 2,593 & $3,654,522$ \\
\hline
\end{tabular}




\section{Results}

The following results were observed from the HEC-RAS simulations without the Merrimack Village Dam in place:

- Once the dam is removed, an ice jam occurring downstream would extend upstream through the Chamberlain Bridge.

- The ice jam surface level, which is $4.5 \mathrm{ft}$ from bridge superstructure, is approximately the same for the two-year and ten-year recurrence interval discharges.

- An ice jam event occurring during the two-year discharge would result in an ice and water surface elevation of approximately $122.0 \mathrm{ft}$, $11 \mathrm{ft}$ higher through the bridge than during a two-year open water event, elevation $111.0 \mathrm{ft}$.

- An ice jam event occurring during the ten year discharge would result in an ice and water surface elevation of approximately $122.25 \mathrm{ft}$, $8.5 \mathrm{ft}$ higher through the bridge than during a ten-year open water event, elevation $113.75 \mathrm{ft}$.

- Ice jams occurring after the dam was removed did not result in significantly more flow out of banks than the open water events.

- Velocities beneath the ice jams were under $8 \mathrm{ft} / \mathrm{s}$ in all areas except immediately upstream of the bridge, where they reached $9.5 \mathrm{ft} / \mathrm{s}$ during the two-year flow and $18 \mathrm{ft} / \mathrm{s}$ during the ten-year flow.

Figures 8- 11 show the HEC-RAS simulation results of the two-year and the ten-year discharges with an ice jam for the dam in place and removed. The open water profile is also shown.

The geo-referenced results were imported into GIS to map the flood inundation with and without the dam in place. Since the original cross sections were used in place of the cross sections cut from the digital elevation map, the flood inundation does not cover all areas of the river, but it can be used for comparison to look at the pre- and post-dam removal conditions. The 
ice jams shown on the maps were digitized by hand to show where the ice jam was modeled in HEC-RAS. Later versions of GeoRAS will allow the user to import the ice jam as well. Figures $12-15$ show the inundated areas due to ice jams at the two-year and ten-year discharges with and without the dam. The open water two-year and ten-year flood inundated areas are also shown.

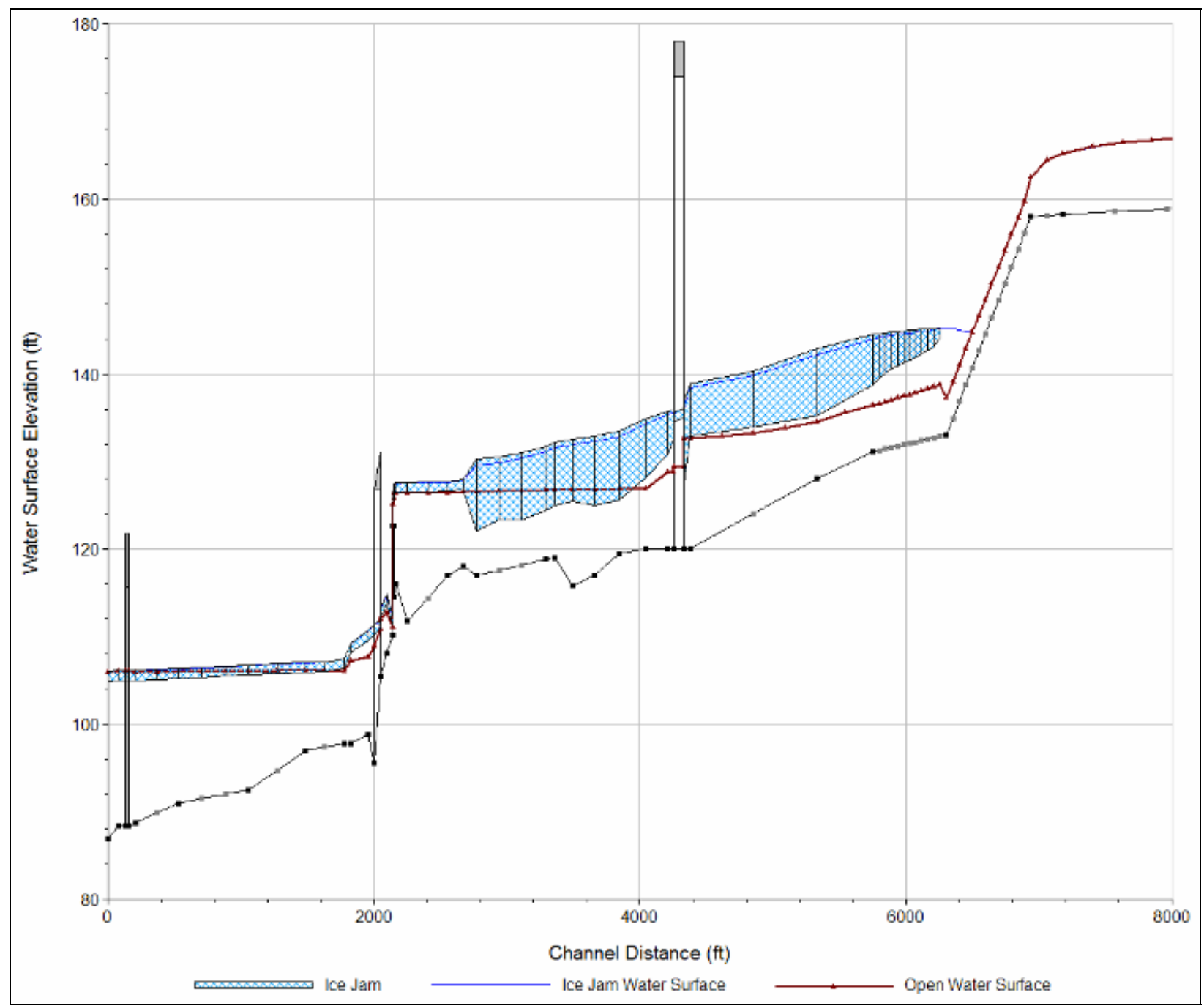

Figure 8. HEC-RAS ice jam and open water profiles, with dam in place for the two-year discharge. 


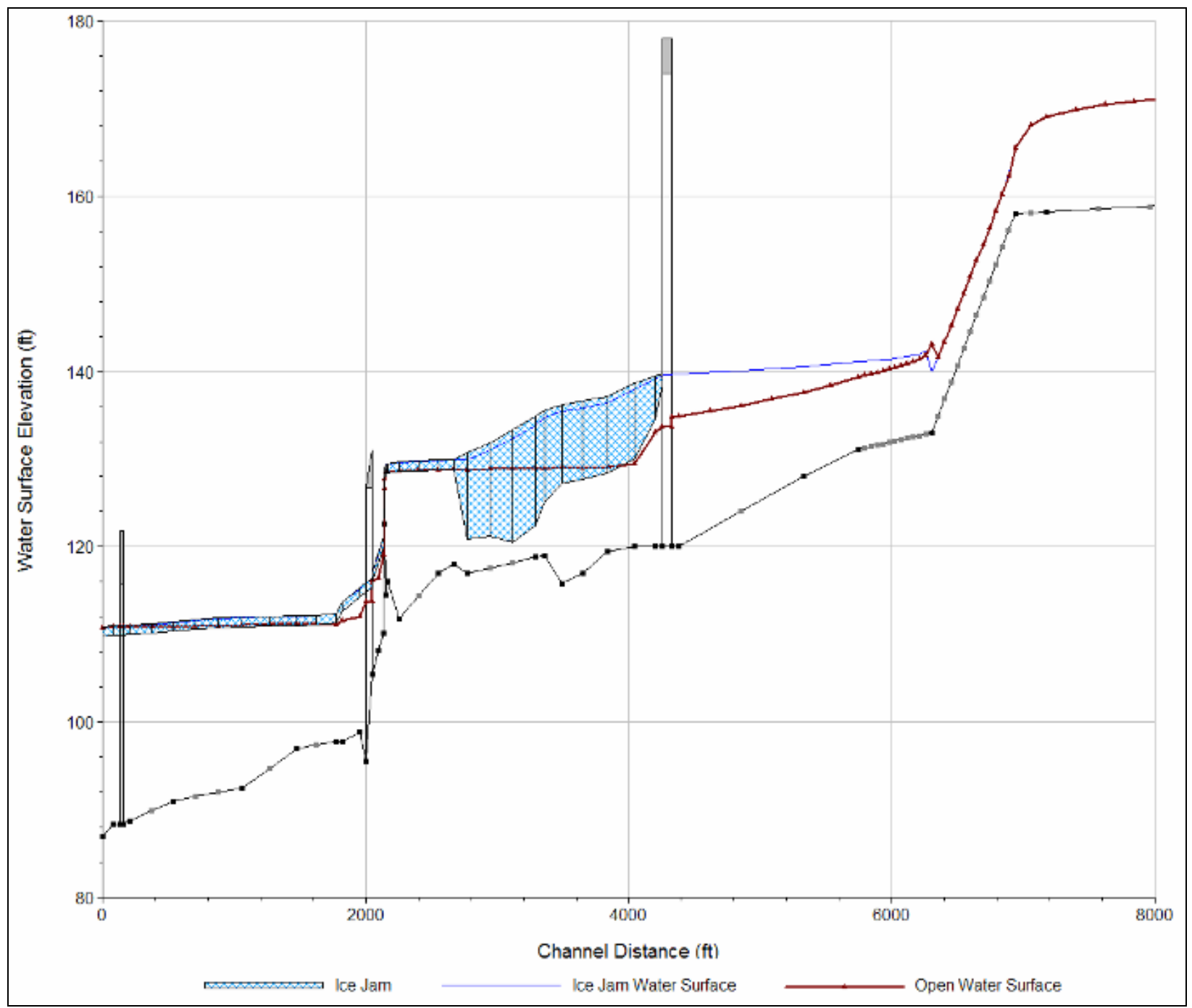

Figure 9. HEC-RAS ice jam and open water profiles, with dam in place for the ten-year discharge. 


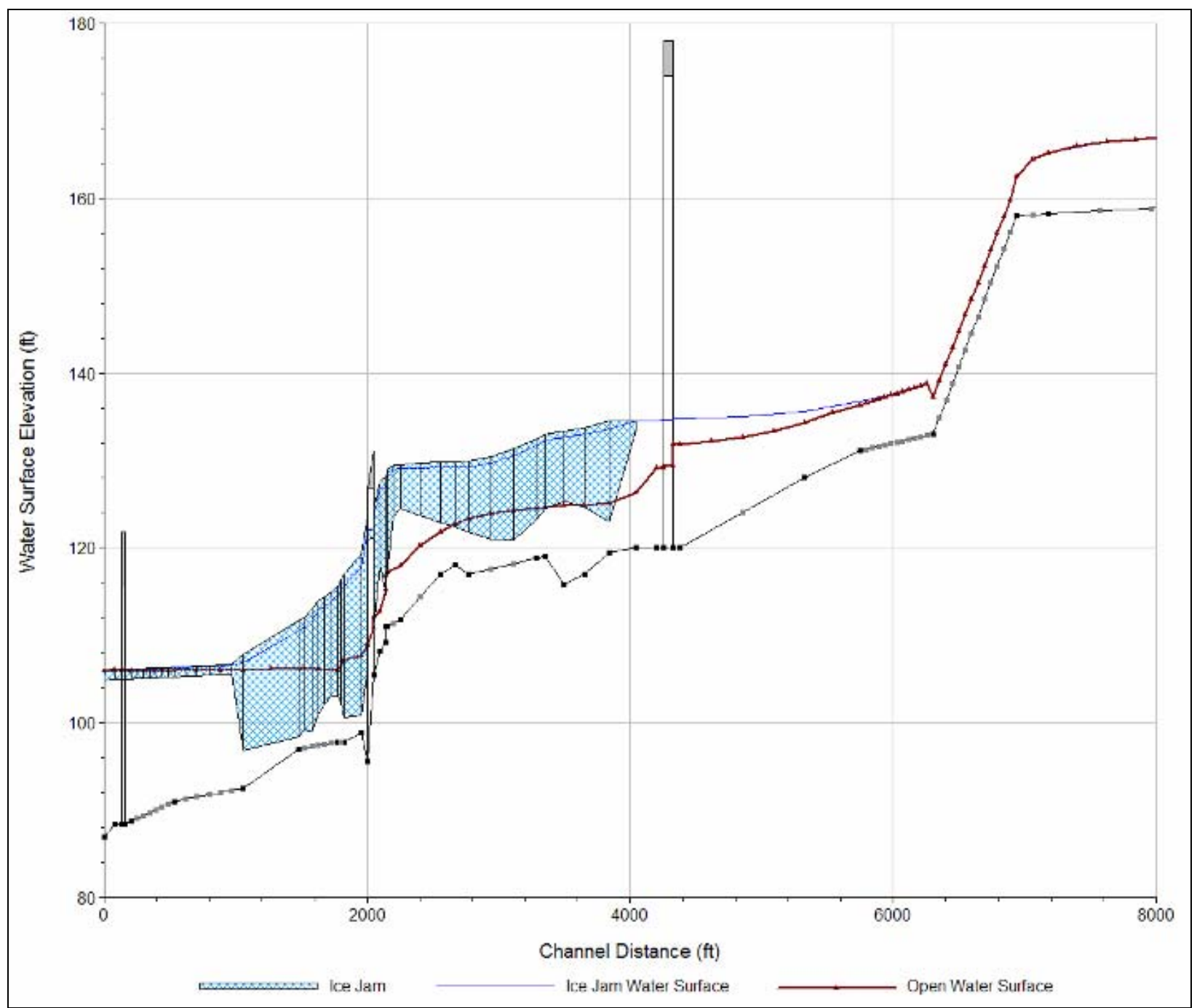

Figure 10. HEC-RAS ice jam and open water profiles, with dam removed for the two-year discharge. 


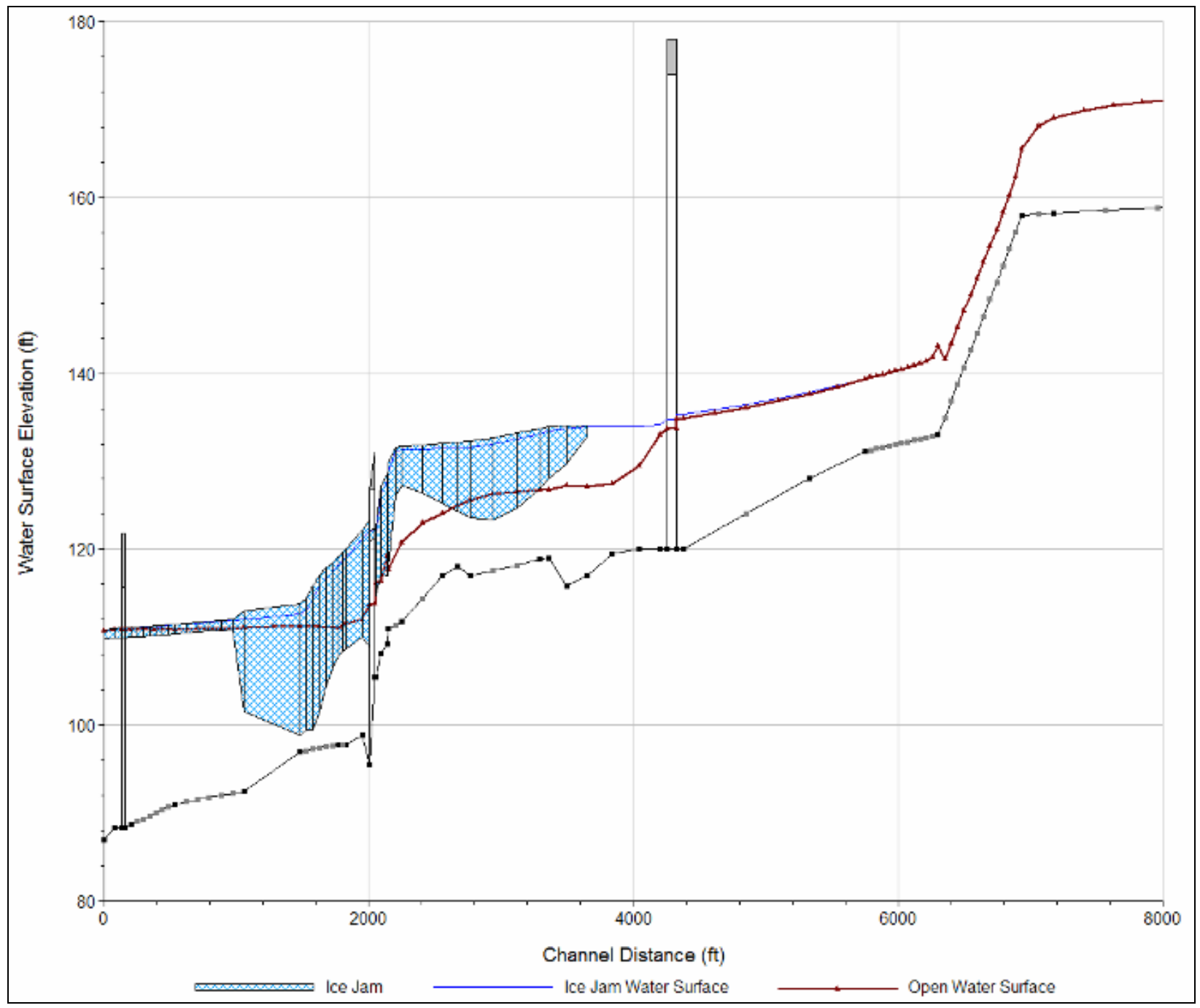

Figure 11. HEC-RAS ice jam and open water profiles, with dam removed for the ten-year discharge. 


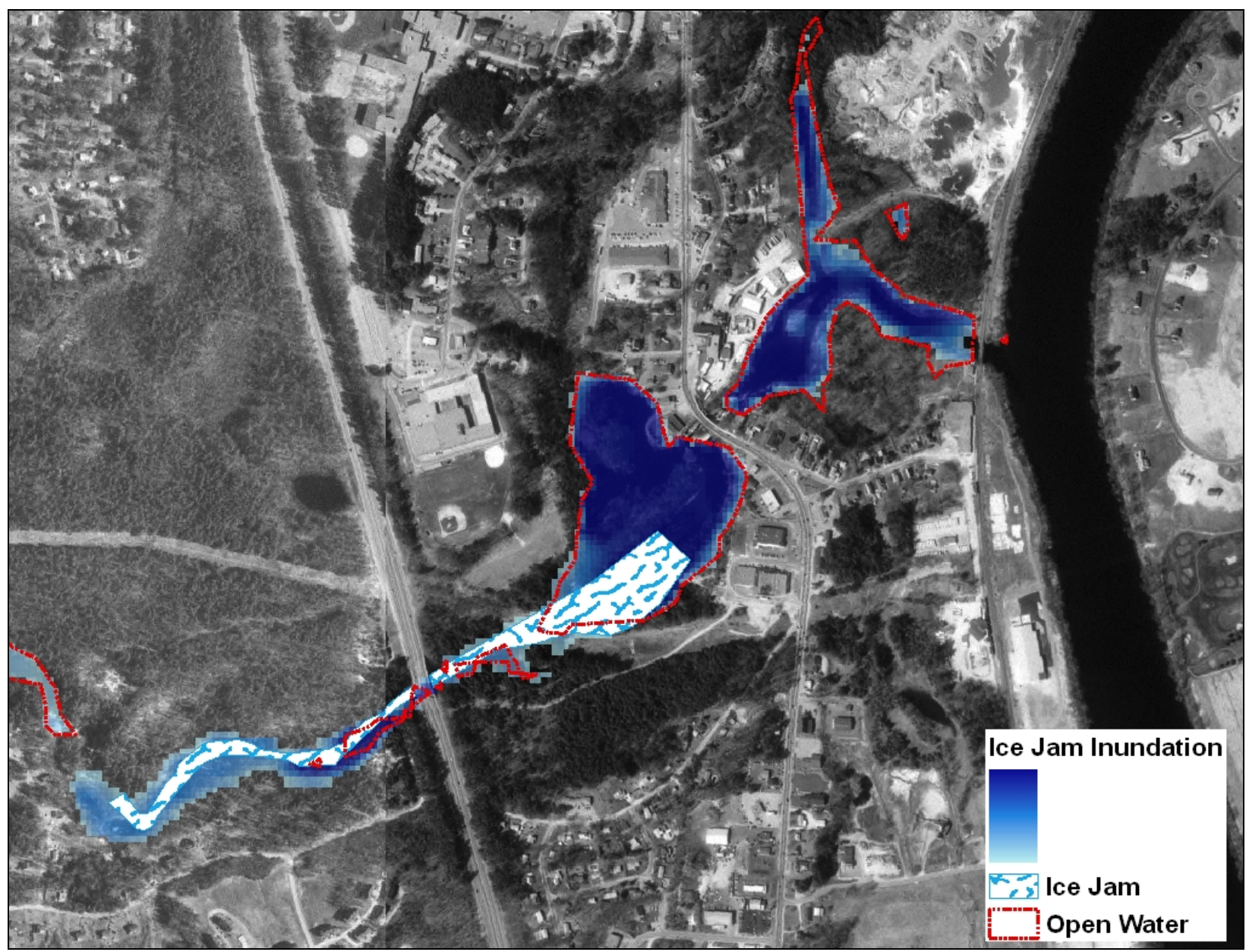

Figure 12. Estimate of ice jam locations and inundated areas with dam in place for the two-year discharge. 


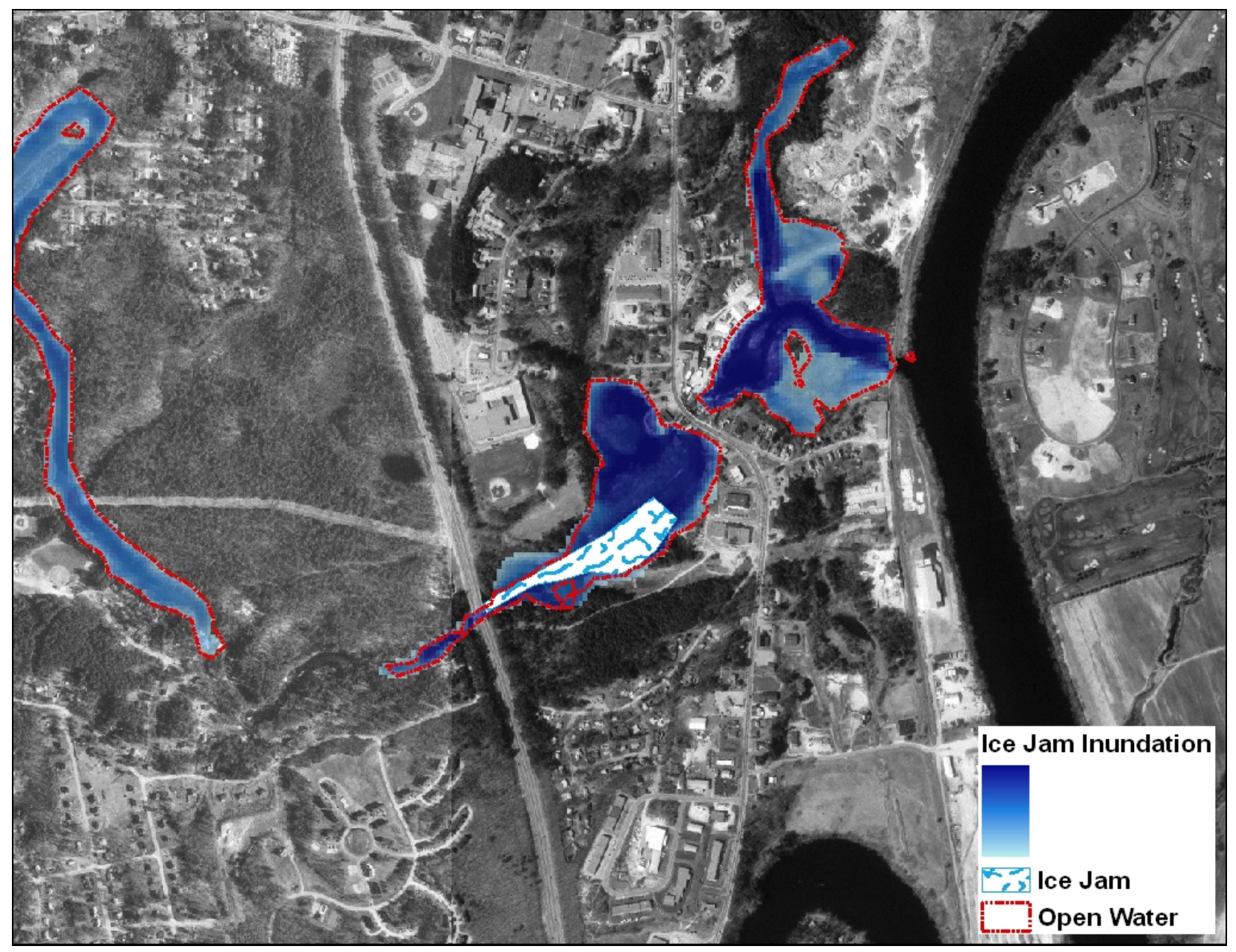

Figure 13. Estimate of ice jam locations and inundated areas with dam in place for the ten-year discharge. 


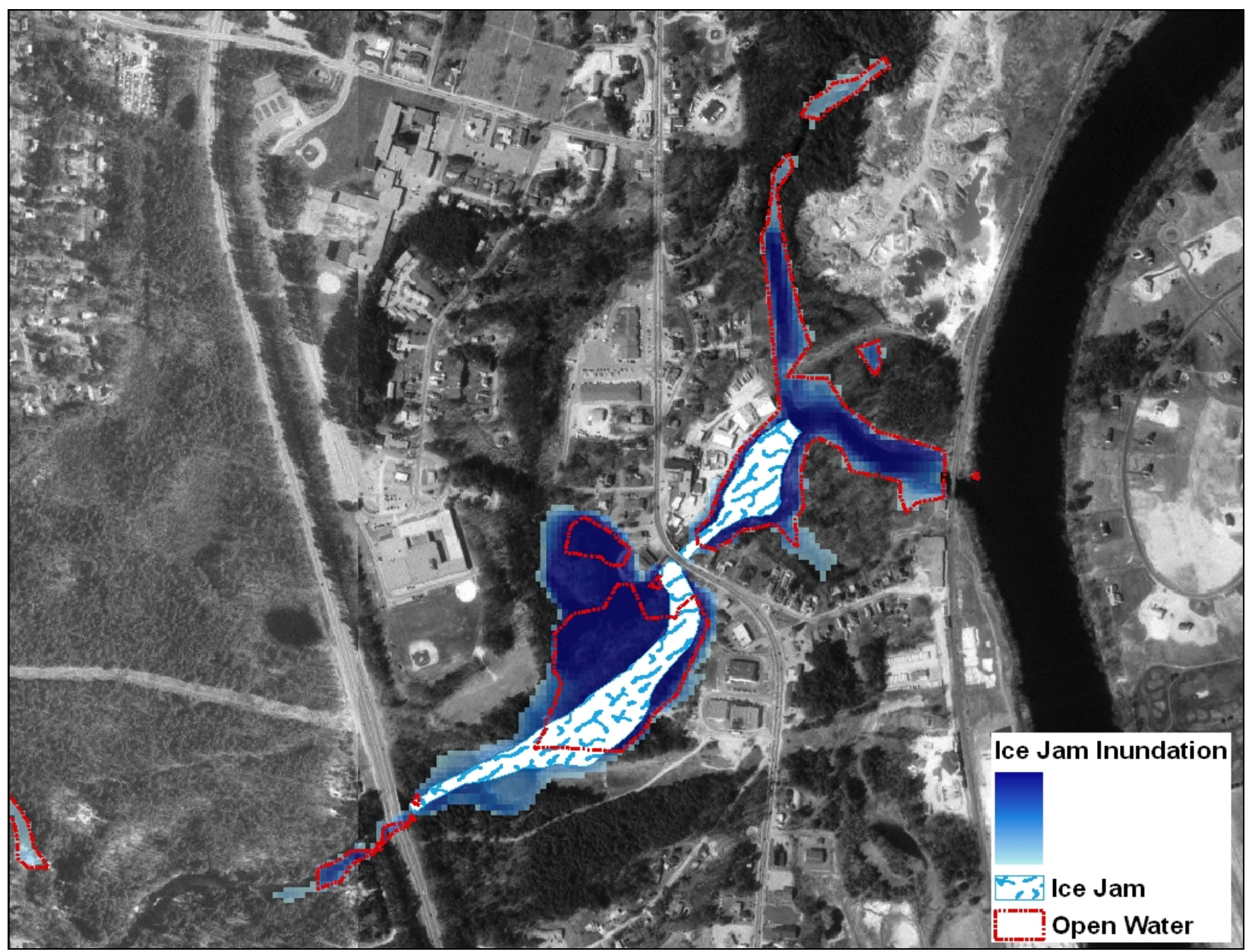

Figure 14. Estimate of ice jam locations and inundated areas with dam removed for the two-year discharge. 


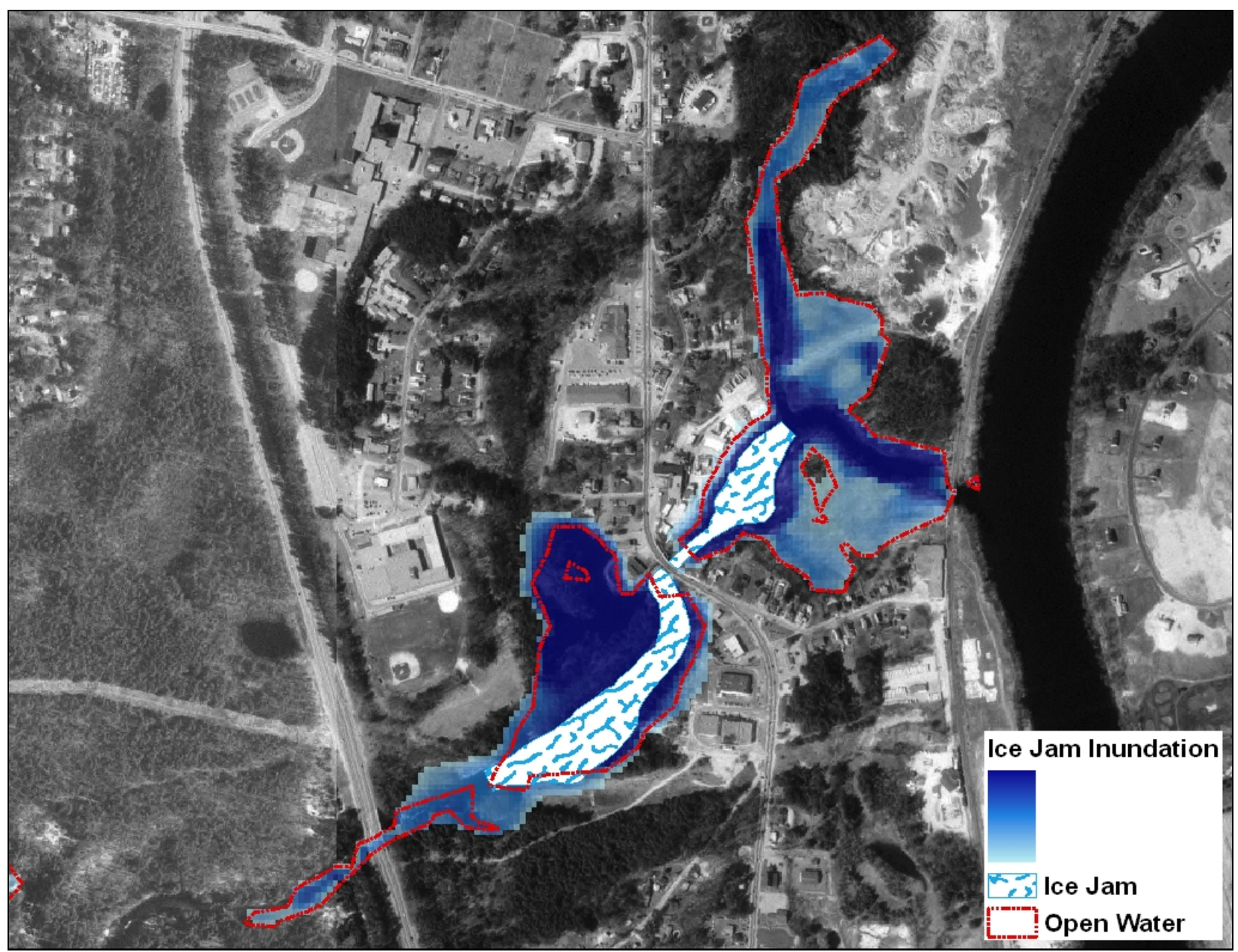

Figure 15. Estimate of ice jam locations and inundated areas with dam removed for the ten-year discharge. 


\section{Ice Impacts Resulting from Merrimack Village Dam Removal}

Based on this analysis, it is estimated that breakup ice runs that currently stop behind the impoundment of the Merrimack Village Dam will travel farther downstream and stop in the backwater of the Merrimack River. Ice jams occurring downstream have the potential to extend upstream through the Chamberlain Bridge, resulting in higher water surface elevations than during similar open water events. Of particular concern is the impact of ice to the historical Chamberlain Bridge. Figure 16 describes the terms used in this report to refer to sections of the Chamberlain Bridge.

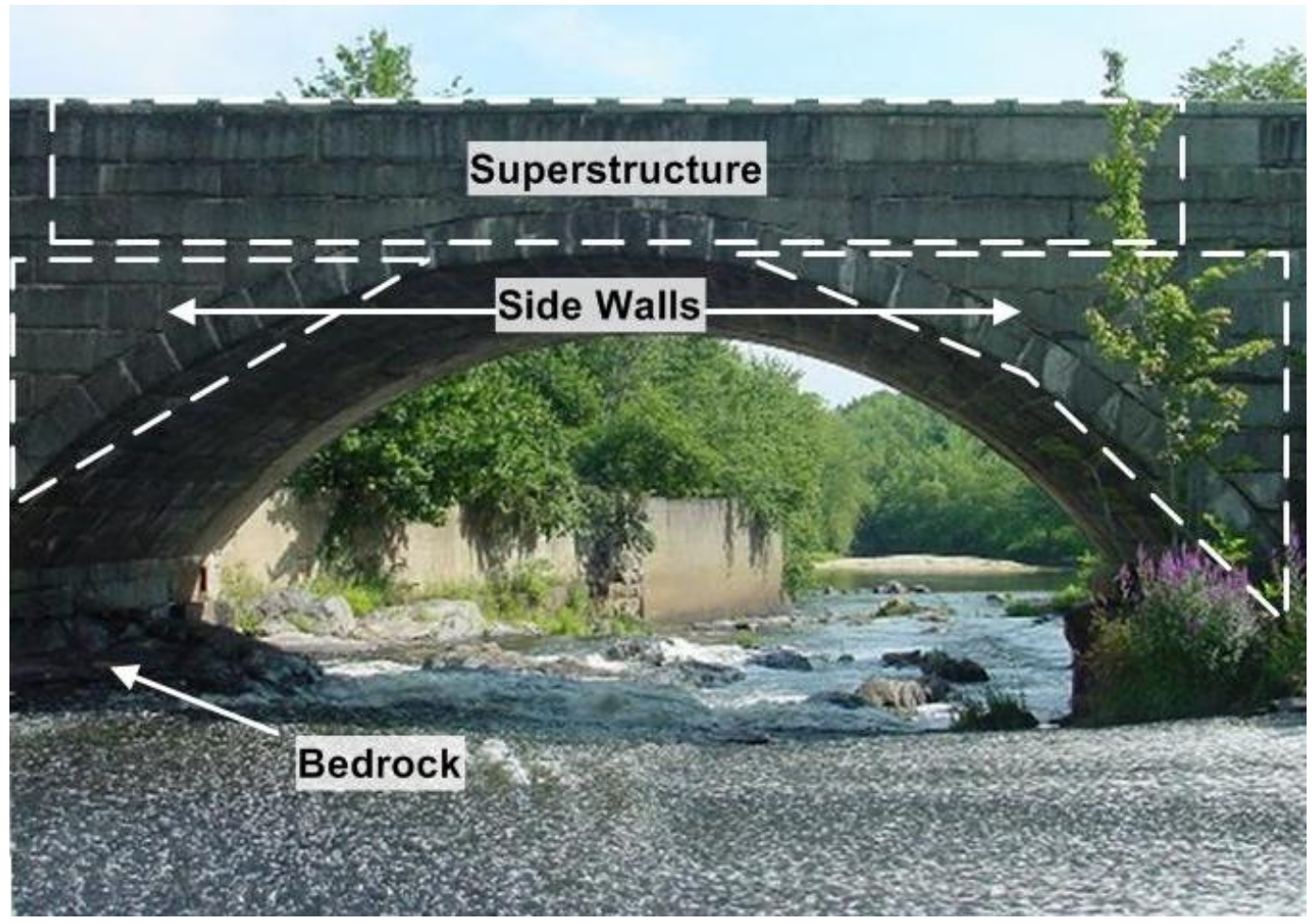

Figure 16. Chamberlain Bridge, looking downstream.

Generally, crushing ice loads acting on the bridge superstructure in the downstream direction provide the greatest risk to the bridge safety. Beltaos et al. (2007) noted that a bridge superstructure is particularly vulnerable to ice loads because of the relatively large area of impact compared to typical bridge piers. The suggested solution is to ensure the water and ice stage levels do not reach the superstructure during bridge design. Ice jams 
modeled on the Souhegan River downstream of the bridge extended upstream through the bridge in both the two-year and the ten-year discharge simulations. In each case, the ice was approximately $4-5 \mathrm{ft}$ below the bridge superstructure. The underside of the Chamberlain Bridge forms an arch that extends between banks. The ice jam extending through the bridge may impact the lower side walls of this arch. Forces acting on the vertical side walls are a result of ice jams and the movement of ice rubble, which tend to be significantly smaller forces than ice crushing forces. Ice forces are expected to act over a height of 12 feet on the face of the side walls and were calculated according to AASHTO (2007), assuming an ice pressure of $0.2 \mathrm{KSF}$. The estimated ice force acting on the side walls during an ice jam event is 24 Kips.

Another concern at bridges is under-ice scour that might destabilize the bridge piers and abutments. The constricted flow area due to the ice cover can result in higher velocities, increased turbulence, and scour of erodible bed material (Zabilansky et al. 2006). Through the Chamberlain Bridge, the slope steepens and velocities greater than $10 \mathrm{ft} / \mathrm{s}$ can be seen during open water flow. However, scour does not appear to be a significant issue at the Chamberlain Bridge, as the bridge is built upon exposed bedrock (Gomez and Sullivan 2004).

With the dam removed, the two-year discharge ice-affected water surface profile was higher through the bridge, and the ice jam extended upstream almost to the F.E. Everett Turnpike Bridge. The ten-year discharge ice jam simulation with the dam removed looked very similar to the two-year simulation. In the ten-year discharge simulation, the water was forced out of bank on the right, downstream of the bridge. This would effectively release pressure on the jam and validates the assumption that the most significant ice jam event would occur between the two-year and ten-year discharge. Based on the flood inundation mapping, it does not appear that ice jams farther downstream will result in significantly higher water surface elevations than during similar open water events. For that reason, increased flooding due to ice jams once the dam is removed does not appear to be a significant issue. 


\section{Summary and Conclusions}

Dam decommissioning and removals are increasingly frequent in the United States for purposes of stream rehabilitation, recreation, and economics. The potential for increased frequency and severity of ice jams resulting from a dam removal on a northern river needs to be investigated during the evaluation phase of a dam decommissioning.

This study investigated the impacts of the Merrimack Village Dam removal on the formation of potentially damaging ice jams in the Souhegan River. In order to achieve that objective, the following steps were taken:

- Historical ice jam reports and river geomorphology were analyzed to determine the most likely location for ice jams to occur once the dam is removed. Historical ice jam information was found at the CRREL Ice J am Database Web site: https:/ / rsgis.crrel.usace.army. $\mathrm{mil} /$ icejam/ .

- Historical meteorological (NWS) and hydrological (USGS) data were used to estimate ice thickness, ice jam volume, and a range of likely discharges during an ice jam event.

- A HEC-RAS hydraulic model of the Souhegan River was georeferenced and used to estimate the ice jam thickness and resulting water surface profiles with and without an ice jam in place for both the pre- and post-dam-removal conditions. Several iterations were necessary to match the ice volume conditions at each discharge.

- The geo-referenced results were imported into GIS to compare the ice jam flood inundation with and without the dam in place.

Based on this analysis the following conclusions were made:

- The most likely location for a breakup ice run to jam once the dam is removed is where it meets the backwater of the Merrimack River, approximately 1,000 feet upstream from the mouth of the Souhegan River at the location of a large sediment island. This analysis assumes that ice currently stopped behind the Merrimack Village 
Dam impoundment will be able to pass farther downstream once the dam is removed.

- An ice jam at this location will extend upstream through the Chamberlain Bridge, resulting in a higher water and ice surface level through the bridge than during an open water event at the same discharge. The ice and water surface levels are not expected to contact the top portion of the bridge or the roadway.

- The ice jam extending through the bridge may impact the vertical side walls of the bridge. Forces acting on the vertical side walls are a result of the movement of ice rubble and tend to be significantly smaller forces than ice crushing forces. The estimated ice force acting on the side walls during an ice jam event is 24 Kips.

- Although scour of erodible bed sediment during ice jams at bridges is often a concern due to the destabilization of bridge piers and abutments, scour does not appear to be an issue at the Chamberlain Bridge, as the bridge was constructed on exposed bedrock.

- Based on the flood inundation mapping, it does not appear that ice jams farther downstream will result in significantly higher water surface elevations in developed areas than during similar open water events. For that reason, increased flooding due to ice jams once the dam is removed does not appear to be a significant issue.

Performing an ice impact study can save money and time and reduce the likelihood of adverse impacts if performed prior to removing the dam. This case study demonstrates the steps required to make an informed decision regarding the impacts of dam removal on the ice jam regime. 


\section{References}

Abdul-Mohsen, A.A. (2005) Economic efficiency and income distribution evaluation of toxics and dam removal using contingent valuation. Ph.D. Thesis, The Ohio State University.

American Association of State Highway and Transportation Officials (AASHTO) (2007) LRFD Bridge Design Specifications, 4th Edition, Washington, DC.

American Institute of Biological Sciences (2002). BioScience-A Special Section on Dam Removal and River Restoration, Vol. 52, No. 8, pp 643- 750.

American Rivers (2002) The ecology of dam removal—A summary of benefits and impacts (http:// www.amrivers.org/ damremovaltoolkit/ ecologyofdamremoval. htm).

American Rivers, Friends of the Earth, and Trout Unlimited (1999) Dam Removal Success Stories. Washington, DC: American Rivers.

American Society of Civil Engineers (1997) Guidelines for Retirement of Dams and Hydroelectric Facilities. Washington, DC: American Society of Civil Engineers.

American Society of Civil Engineers (2005) Report Card for America's Infrastructure, 2005 (http:// www.asce.org/ reportcard/2005/ page.cfm?id=203).

Bednarek, A. (2001) Undamming rivers: A review of the ecological impacts of dam removal. Environmental Management, Vol. 27, No. 6, pp :803-814.

Beltaos, S., and W.J . Moody (1986). Measurements of the configuration of a breakup jam. Contribution No. 86-123, National Water Research Institute, Burlington, Canada.

Beltaos, S., L. Miller, B.C. Burrell, and D. Sullivan (2007) Hydraulic effects of ice breakup on bridges. Canadian J ournal of Civil Engineering, Vol. 34, pp 539- 548.

Born, S.M., K.D. Genskow, T.L. Filbert, N. Hernandez-Mora, M.L. Keefer, and K.A. White (1998) Socioeconomic and institutional dimensions of dam removals: The Wisconsin experience. Environmental Management, Vol. 22, No. 3, pp 359- 370.

Bowles, D.S., L.R. Anderson, T.F. Glover, and S.S. Chauhan (1999) Understanding and managing the risks of aging dams: Principles and case studies. Proceedings, Nineteenth USCOLD Annual Meeting, Atlanta, Georgia, May 16-21, 1999 (http:// www.engineering.usu.edu/ uwrl/ www/ faculty/ DSB/ USCOLD99.PDF).

Conyngham, J ,. J .F. Fischenich, and K.D. White (2006) Engineering and ecological aspects of dam removal: An overview. EMRRP Technical Notes Collection (ERDCTN-EMRRP-SR80), Vicksburg, MS: US Army Engineer Development Center (http://el.erdc.usace.army.mil/emrrp/). 
Daly, S.F., G. Brunner, S. Piper, M. J ensen, and A.M. Tuthill (1998) Modeling IceCovered Rivers Using HEC-RAS. In Proceedings, 9th International Conference on Cold Regions Engineering, Cold Regions Impact on Civil Works (David E. Newcomb, Ed.), Duluth, Minnesota, September 27- 30, 1998. Reston, VA: American Society of Civil Engineers, 373- 383.

Doyle, M.W, E.H. Stanley, J .M. Harbor, and G.G. Grant (2003) Dam Removal in the United States: Emerging Needs for Science and Policy. EOS, Transactions of the American Geophysical Union,Vol. 84, No. 4, pp. 29- 31.

FEMA (1979) Flood Insurance Study, Town of Merrimack, NH. Prepared by US Department of Housing and Urban Development, December 1979.

FEMA (2001) National Dam Safety Program (http:// www.fema.gov/fima/ damsafe/).

Flato, G., and R. Gerard (1986) Calculation of Ice J am Thickness Profiles. $4^{\text {th }}$ Workshop of Hydraulic of River Ice, 19-20 J une 1986, Montreal, Quebec, Canada.

Gerard, R.L., and E.W. Karpuk (1979) Probability analysis of historical flood data. J ournal of the Hydraulics Division, ASCE, 105(HY9): 1153- 1165.

Gomez and Sullivan, Inc. (2004) Merrimack Village Dam Final Report: Phase 1-Dam Removal Feasibility Study. Prepared for Pennichuck Water Works, December 2004.

Healy, D., F. Hicks, and S. Beltaos (1997) A comparison of the ICEJ AM and RIVJ AM Ice J am Profile Models, Proceedings, 9th Workshop on River Ice, 24- 26 September 1997, Fredericton, New Brunswick, p. 269- 288.

Heinz Center (2002) Dam Removal: Science and Decision Making. Washington, D.C.: H. J ohn Heinz III Center for Science, Economics and the Environment.

IJ DB (2007) CRREL Ice J am Database (http:// www.crrel.usace.army.mil/ierd/ijdb/), accessed March 2007.

Kuby, M.J., W.F. Fagan, C.S. ReVelle, W.L. Graf (2005) A multiobjective optimization model for dam removal: An example trading off salmon passage with hydropower and water storage in the Willamette basin. Advances in Water Resources (28): 845- 855.

Lever, J .H., G.E. Gooch, and S.F. Daly (2000) Cazenovia Creek Ice-Control Structure. US Army Engineer Research and Development Center, Cold Regions Research and Engineering Laboratory, Hanover, NH, Technical Report ERDC-CRREL TR-0014 (http:// www.crrel.usace.army.mil/techpub/CRREL Reports/reports/TR0014.pdf).

MoGrath, S. (2000) Risk Assessment in Dam Management. The Winston Churchill Memorial Trust of Australia.

National Research Council (1992) Restoration of Aquatic Ecosystems: Science, Technology, and Public Policy. National Academy Press: Washington, DC.

NPDP (2005) National Performance of Dams Program Database (http:// npdp.stanford. edu/index.html\#), accessed 17 March 2005. 
Tanimoto, K. (2003) Cost allocation in dam removal project. Proceedings, IEEE International Conference on Systems, Man and Cybernetics, Washington, DC, 5- 8 October 2003, Volume 4, p. 3308-3313.

Tuthill, A.M. (in prep) Grasse River Ice Control Structure; Physical Model Study. US Army Engineer Research and Development Center, Cold Regions Research and Engineering Laboratory, Hanover, NH. Contract report for Alcoa.

Tuthill, A.M., and G. Gooch (1998) Physical model study of ice retention booms, 14th International Symposium on Ice, Potsdam, NY, 27-31J uly, 1998, p. 61- 66.

Tuthill, A. M., and K.D. White (1997) Breakup ice control structure for the Salmon River in Connecticut. Proceedings, 9th Workshop on River Ice, Fredericton, NE, 125139.

Tuthill, A.M., J .L. Wuebben, S.F. Daly, and K.D. White (1996) Probability distributions for peak stage on rivers affected by ice jams. ASCE J ournal of Cold Regions Engineering, Vol. 10, No. 1, p. 36- 57.

Tuthill, A.M., J .L. Wuebben, J .J . Gagnon (1998) ICETHK User's Manual, Version 1. US Army Cold Regions Research and Engineering Laboratory, Hanover, NH, Special Report 98-11 (http:/ / www.crrel.usace.army.mil/techpub/CRREL_Reports/ reports/SR98 11.pdf).

Tuthill, A.M., C.M. Vuyovich, and K.D. White (2003) Ice-affected stage-frequency development along the Connecticut River. Proceedings, 12th Workshop on the Hydraulics of Ice Covered Rivers, 19- 20 J une 2003, Edmonton, AB, Canada.

Tuthill, A.M., K.D. White, and C.M. Vuyovich (2007) Ice J ams, Contaminated Sediment, Dam Removal, and Bridge Scour on the Clark Fork River, Montana. 14th Workshop on Ice Covered Rivers, 19-22 J une 2007, Quebec, Canada.

USACE (1980) Historical Ice J am Flooding in Maine, New Hampshire, and Vermont. Section 206: Flood Plain Management Assistance Report, prepared by New England Division.

USACE (2002) Engineering and Design-Ice Engineering. US Army Engineer Manual 1110-2-1612 (http:// www.usace.army.mil/inet/usace-docs/eng-manuals/ em11102-1612/toc.htm).

USACE (2005a ) National Inventory of Dams (http:// crunch.tec.army.mil/nid/ webpages/nid.cfm), accessed 17 March 2005.

USACE (2005b) GIS Tools for support of HEC-RAS using ArcGIS, HEC Report CPD 83, US Army Corps of Engineers Hydrologic Engineering Center: Davis, CA (http:// www.hec.usace.army.mil/software/ hec-ras/ documents/HEC-GeoRAS4 UsersManual.pdf).

USACE (2006) HEC-RAS River Analysis System User's Manual, Version 4.0 Beta. HEC Report CPD 68, US Army Corps of Engineers Hydrologic Engineering Center: Davis, CA (http:/ / www.hec.usace.army.mil/software/ hec-ras/ hecrasdocument.html). 
USGS (2007a) Real-time water data for USGS 01094000, Souhegan River at Merrimack, $\mathrm{NH}$ (http:// waterdata.usgs.gov/ usa/nwis/ uv?site no=01094000), accessed April 2007.

USGS (2007b) Real-time water data for USGS 01092000, Merrimack River gage at Goffs Falls (http:/ / waterdata.usgs.gov/ usa/ nwis/ uv?site no=01092000), accessed April 2007.

Vuyovich, C.M., and K.D. White (2006) Assessment of the Effectiveness of the Israel River Ice Control Structure, Lancaster, NH. US Army Engineer Research and Development Center, Cold Regions Research and Engineering Laboratory, Hanover, NH, Technical Report ERDC-CRREL TR-06-1 (http:/ / www.crrel. usace.army.mil/techpub/CRREL_Reports/reports/TR06-1.pdf).

Vuyovich, C.M., A.M. Tuthill, S.F. Daly, and K.D. White (2005) Ice Impact Evaluation for the Lower Connecticut River Map Modernization, Hampden County, MA, and Hartford and Middlesex Counties, CT. Report prepared for the Federal Emergency Management Agency, Region 1.

White, K.D. (1999) Hydraulic and Physical Properties Affecting Ice J ams. US Army Cold Regions Research and Engineering Laboratory, Hanover, NH, CRREL Report 9911 (http:// www.crrel.usace.army.mil/techpub/CRREL_Reports/reports/CR99 11.pdf).

White, K.D. (2001) Considerations for Dam Removal in Ice-Affected Rivers. Ice Engineering Bulletin, USACE Cold Regions Research and Engineering Laboratory, Vol. 27, J anuary 2001 (http:// 144.3.144.33/ tectran/27InDesign.pdf).

White, K.D. (2004) Method to Estimate River Ice Thickness Based on Meteorological Data. US Army Engineer Research and Development Center, Cold Regions Research and Engineering Laboratory, Hanover, NH, Technical Note ERDCCRREL TN-04-3. (http:// www.crrel.usace.army.mil/techpub/CRREL_Reports/ reports/TN04-3.pdf).

White, K.D. and J.N. Moore (2002) Impacts of Dam Removal on Riverine Ice Regime, ASCE J ournal of Cold Regions Engineering, Vol 16, No. 1, March 2002

White, K.D., and S.F. Daly (1997) The effects of uncertainty in ice roughness on equilibrium ice thickness and stage. Proceedings, 9th Workshop on River Ice, 24- 26 September 1997, Fredericton, New Brunswick, p. 89-99.

Zabilansky, L.J ., D.B. Hains, and J .I. Remus (2006) Increased Erosion Due to Ice. Proceedings of the 13th International Conference on Cold Regions Engineering, 23-26 J uly 2006, Orono, Maine. 


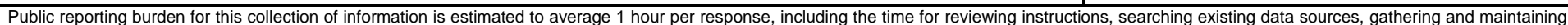

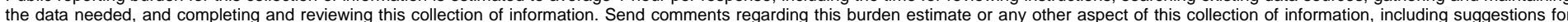

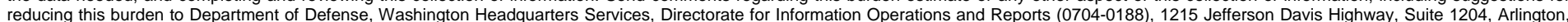

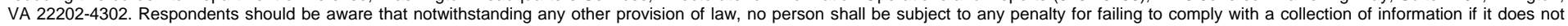
display a currently valid OMB control number. PLEASE DO NOT RETURN YOUR FORM TO THE ABOVE ADDRESS.
1. REPORT DATE (DD-MM-YYYY)
September 2007

\section{Technical Report}

4. TITLE AND SUBTITLE

Evaluation of Dam Decommissioning in an Ice-Affected River: Case Study
3. DATES COVERED (From - To)

5a. CONTRACT NUMBER

5b. GRANT NUMBER

5c. PROGRAM ELEMENT NUMBER

5d. PROJECT NUMBER

5e. TASK NUMBER

5f. WORK UNIT NUMBER

8. PERFORMING ORGANIZATION REPORT NUMBER

ERDC/CRREL TR-07-18

10. SPONSOR/MONITOR'S ACRONYM(S)

11. SPONSOR/MONITOR'S REPORT NUMBER(S)

\section{DISTRIBUTION / AVAILABILITY STATEMENT}

Approved for public release; distribution is unlimited.

Available from NTIS, Springfield, Virginia 22161.

13. SUPPLEMENTARY NOTES

\section{ABSTRACT}

Many dams across the United States are being decommissioned as a result of structural deficiencies or a desire to restore fish passage and to restore the natural stream. On northern rivers, dam removal affects the river ice processes and can result in increased ice jams and ice jam-related flooding. An analysis of the river system prior to dam removal is often necessary to ensure that increased ice jams, flooding, and damages do not result. This case study presents the types of analyses needed to investigate the ice impacts of the potential removal of the Merrimack Village Dam on the Souhegan River in Merrimack, New Hampshire. Of particular interest were the potential impacts to the historic Chamberlain Bridge. A HEC-RAS hydraulic model was used to estimate the ice jam thickness and resulting water surface profiles with and without an ice jam in place for both the pre- and post-dam-removal conditions. The results of this analysis indicate that removing the Merrimack Village Dam will not pose significant risk to the Chamberlain Bridge or to the area downstream.

\section{SUBJECT TERMS}

Bridges, Dam removal, Flooding, HEC-RAS, Ice impact study, Ice jams, Souhegan River

16. SECURITY CLASSIFICATION OF:

\section{a. REPORT}

U

\section{b. ABSTRACT}

$\mathrm{U}$
17. LIMITATION OF ABSTRACT c. THIS PAGE
$\mathrm{U}$
18. NUMBER OF PAGES

$\mathrm{U}$
48 19a. NAME OF RESPONSIBLE PERSON

19b. TELEPHONE NUMBER (include area code) 